УДК 902/904, 902.03, 930.85, 292/299, 299.1

МРНТИ 03.41.91

https://doi.org/10.52967/akz2021.4.14.64.91

\title{
История открытия и изучения первого манихейского храма в Сибири. Часть 2
}

\section{(С) 2021 г. Кызласов И.Л.}

Keywords: archaeology, history of science, scientific approaches, archaeological methods, adobe temples, Siberian-Turkic manichaeism

Түйін сөздер: археология, ғылым тарихы, ғылыми тәсілдер, археологиялық әдістер, шитті храмдар, сібір-түркі манихейлігі

Ключевые слова: археология, история науки, научные подходы, археологические методы, сырцовые храмы, сибирско-тюркское манихейство

\author{
Igor Kyzlasov ${ }^{1}$ \\ ${ }^{1}$ Professor Doctor of Historical Sciences, Leading Researcher, Institute of Archeology, \\ Russian Academy of Sciences, Moscow, Russia. E-mail: kyzlasovil@mail.ru
}

The history of the discovery and study of the first Manichaean temple in Siberia. Part 2

\begin{abstract}
This article is a continuation of the first part published in the previous issue of the journal. Field experience gained during excavations of religious buildings on the AkBeshim settlement in Kyrgyzstan in 1953-1954 was transferred by L. Kyzlasov to Southern Siberia and successfully applied in 1971-1981. The first Manichaean church in the Sorgá (Khakassia) basin was discovered and studied, and then a whole series of similar sacred buildings in the lower reaches of the river Uybat, too, which since 1974 has been dug up during eight field seasons. Large-scale, long-term excavation work in the second discovered temple and monastery center, the processing of their results and a constant comparative and generalizing analysis of all materials obtained by field studies over the years led to an accurate religious definition of all 12 churches and sanctuaries studied. The views coming from antiquity, manifested in temple architecture, turned out to be decisive - the veneration of 7 celestial luminaries led to the development and canonization of the architectural and planigraphic symbolism of cult structures, which differed in shape for each of these celestial bodies and sacrally significant cosmic phenomena. The list of geometric diversity of the layouts of Manichaean temples, contained in the essay of al-Masudi ( $10^{\text {th }}$ century), was confirmed and supplemented with the testimonies of al-Shakhristani $\left(12^{\text {th }}\right.$ century) and adDimeshki $\left(14^{\text {th }}\right.$ century). These data allowed L. Kyzlasov to understand in all the basic details the previously unprecedented variety of the structure of temple buildings and sanctuaries of both religious centers of Khakassia encountered during excavations. Then and to this day, Manichaean temples were and remain unknown to archaeologists - the science of antiquities has revealed a completely new page not only in Siberian studies, but also in turkological oriental studies as a whole.
\end{abstract}

Acknowledgement: Work is performed within the state task AAAA-A18-118011790092-5 "Archaeological and anthropological sources and verification of hypotheses: methodical aspects of fundamental knowledge and field researches" 
For citation: Kyzlasov I. History of the discovery and study of the first Manichaean temple in Siberia. Part 2. Kazakhstan Archeology. 2021, 4 (14), 64-91 (in Russian). DOI: $10.52967 / \mathrm{akz} 2021.4 .14 .64 .91$

Кызласов Игорь Леонидович ${ }^{1}$

${ }^{1}$ тарих ғылымдарының докторы, жетекші ғылыми қызметкер, PҒА Археология институты, Мәскеу қ., Ресей. E-mail: kyzlasovil@mail.ru

\title{
Сібірдегі алғашқы манихей храмының ашылу және зерттелу тарихы. 2-бөлім
}

\begin{abstract}
Аннотация. Бұл мақала журналдың алдыңғы санында жарияланған бірінші бөлімнің жалғасы. 1953-1954 жылдары Қырғызстандағы Ақбешім қалашығында табыну ғимараттарын қазу кезінде алынған далалық тәжірибені Л.Р. Кызласов 19711981 жылдары Оңтүстік Сібірде сәтті қолданды. Сорга (Хакасия) бассейнінде алғашқы манихей ғибадатханасы табылды және зерттелді, содан кейін 1974 жылдан бастап 8 далалық маусымында қазылған Уйбат өзенінің төменгі ағысында осындай қасиетті ғимараттардың тұтастай топтамасы табылды. Екінші ашылған ғибадатхана-монастырь орталығында кең көлемді, ұзақ мерзімді қазба жұмыстарын жүргізу, олардың нәтижелерін өңдеу және далалық зерттеулерден алынған барлық материалдарды үнемі салыстырмалы және жалпылама талдау жылдар бойы зерттелген 12 ғибадатхана мен қасиетті орындардың нақты діни анықтамасына әкелді. Ежелгі дәуірден келе жатқан ғибадатханалық сәулет өнерінде көрініс тапқан айқындаушы көзқарастар болуы 7 аспан денелерін құрметтеу осы аспан денелерінің әрқайсысы үшін және қасиетті маңызды ғарыштық құбылыстар үшін әр түрлі болатын діни ғимараттардың сәулетпланиграфиялық символизмінің дамуы мен канонизациясына әкелді. Ал-Масуди (X ғ.) шығармасындағы манихей ғибадатханаларының геометриялық әралуандылығының тізбесін аш-Шахристани (XII ғ.) және ад-Димешки (XIV ғ.) дәлелдерімен растауға және толықтыруға болады. Бұл мәліметтер Л.Р. Кызласовқа қазба жұмыстары кезінде кездескен Хакасияның ғибадатханалық ғимараттары мен екі діни орталығының ғибадатханаларының бұрын-соңды болмаған алуан түрлілігін түсінуге мүмкіндік берді. Ежелгі заман туралы ғылым болып табылатын манихей храмдары тек сібіртануда ғана емес, сонымен бірге жалпы түркологиялық шығыстануда да жаңа бетті ашты және содан бері әлі күнге дейін археологтарға белгісіз болып келеді және солай болып қала береді.
\end{abstract}

Алғыс: Жұмыс AАA-A18-118011790092-5 «Археологиялық және антропологиялық көздер және гипотезаларды тексеру: іргелі білім мен далалық зерттеулердің әдістемелік аспектілері» тақырыбындағы мемлекеттік тапсырма аясында орындалды

Сілтеме жасау үшін: Кызласов И.Л. Сібірдегі алғашқы манихей шіркеуінің ашылуы және зерттеу тарихы. 2-бөлім. Қазақстан археологиясы. 2021. № 4 (14). 64-91-бб. (Орысша). DOI: 10.52967/akz2021.4.14.64.91

\section{Кызласов Игорь Леонидович ${ }^{1}$}

${ }^{1}$ доктор исторических наук, ведущий научный сотрудник, Институт археологии РАН, г. Москва, Россия. E-mail: kyzlasovil@mail.ru

Аннотация. Данная статья - продолжение первой части, опубликованной в предыдущем номере журнала. Полевой опыт, полученный при раскопках культовых зданий на городище Ак-Бешим в Кыргызстане в 1953-1954 гг,, был перенесен Л.Р. Кызласовым в Южную Сибирь и успешно применен в 1971-1981 гг. Был обнаружен и изучен первый манихейский храм в котловине Сорга́ (Хакасия), а затем и целая серия подобных сакральных построек в низовьях р. Уйбат, которая уже с 1974 г. раскапывалась в течение 
8-ми полевых сезонов. Проведение крупномасштабных, длительных раскопочных работ во втором обнаруженном храмово-монастырском центре, обработка их результатов и постоянный сравнительный и обобщающий анализ всех материалов, полученных полевыми исследованиями, с годами привели к точному религиозному определению всех 12-ти изученных храмов и святилищ. Определяющими оказались идущие из древности взгляды, проявившиеся в храмовом зодчестве, - почитание 7 небесных светил привело к выработке и канонизации архитектурно-планиграфического символизма культовых сооружений. Они отличались по форме для каждого из этих небесных тел и сакрально значимых космических явлений. Перечень геометрического многообразия планировок манихейских храмов, содержащийся в сочинении ал-Масуди (X в.), удалось подтвердить и дополнить свидетельствами аш-Шахристани (XII в.) и ад-Димешки (XIV в.). Эти данные позволили Л.Р. Кызласову во всех основных деталях понять встреченное им при раскопках ранее невиданное разнообразие устройства храмовых зданий и святилищ обоих культовых центров Хакасии. Тогда и поныне манихейские храмы были и остаются неизвестными археологам - наука о древностях раскрыла совершенно новую страницу не только в сибиреведении, но и в тюркологическом востоковедении в целом.

Благодарности: Работа выполнена в рамках государственного задания АААА-А18118011790092-5 «Археологические и антропологические источники и верификация гипотез: методические аспекты фундаментального знания и полевых исследований»

Для цитирования: Кызласов И.Л. История открытия и изучения первого манихейского храма в Сибири. Часть 2. Археология Казахстана. 2021. № 4 (14). С. 64-91. DOI: $10.52967 / \mathrm{akz} 2021.4 .14 .64 .91$

Человеку искусному в ремесле
Две жизни надобно в этой жизни,
Дабы в одной он опыт накопил,
В другой этот опыт в дело
претворил.

Саади Ширази. XIII в.

\section{Введение}

В первой части этой статьи (см. [Кызласов 2021]) показано как археологическая самоподготовка позволила Л.Р. Кызласову в первые послевоенные годы овладеть поисковыми признаками храмов, выстроенных из сырцового кирпича. Успешный опыт отыскания и раскопок буддийского храма (Объект I) и несторианской церкви (Объект IV) на городище Ак-Бешим в Кыргызстане в 1953-1954 гг. способствовал выработке особой методики их археологического вскрытия. Вто- рая часть статьи посвящена рассмотрению того, как этот полевой опыт был перенесен в Южную Сибирь и успешно применен в 1971-1981 гг., в результате чего был обнаружен и изучен первый манихейский храм в котловине Сорга́ (Хакасия), а затем и целая серия подобных сакральных построек. Археологическая наука раскрыла совершенно новую страницу не только в сибиреведении, но и в тюркологическом востоковедении в целом. 
Кызласов И.Л. История открытия и изучения первого манихейского храма в Сибири. Часть 2

Особенности обнаружения $u$ изучения первого храма

Лето 1971 г. было дождливым, поэтому немногочисленный состав Хакасской археологической экспедиции МГУ, проводивший раскопки подле стоявших в полях изваяний и менгиров, с 9 июля базировался в пришкольной избушке поселка железнодорожной станции Ербинская. На следующий день после прибытия были обследованы окрестные скульптуры и стоячие монолиты-менгиры, а уже 11 июля в личном полевом дневнике Л.Р. Кызласова (домашний архив, ХАЭ-71, лл. 16-19) появляется следующая запись: «Осмотрел на самой станции по улице Степной у дома № 108 странный "Большой” курган, имеющий вид прямоугольника, размерами $37,7 \times 31,5$ м, со сторонами, обращенными точно по сторонам света. Внутри прямоугольника пустое пространство - “дворик” 22,4×11,3 м, вытянутый с востока на запад. Высота “валов” (стен) от окружающей поверхности около 3 м, а изнутри - 2,25. Сверху “валы” имеют впадины по углам и по одной в центре (диаметром $2,6-3,4-7,7$ м). С юго-восточной стороны отходят от угла 2 рва и 2 вала остатки “ворот" (?).

В целом все это несколько напоминает древние среднеазиатские “цитадели” и “замки”. Сходство подчеркивает фактура "глинобитных" стен, имеющих (с западной стороны кургана) горизонтальную слоистость и даже вид старинных сырцовых кирпичей. Под глинобитной стеной в Ю3 углу видны большие гранитные валуны, лежащие как бы в фундаменте под глинобитной стеной.

Сверху “валов", вокруг впадин, также кое-где лежат гранитные валуны - откуда они (с крыши?) - неясно. Вряд ли это погребальное сооружение - оно уникально по своей конструкции. По размерам оно приближается к тагарским курганам, но не имеет ограды, да и форма его прямоугольна. Скорее всего - это остатки здания “замка". Дата не установлена, но скорее средневековье. Напрашиваются строки орхоники "с ханом кыргызов мы сразились в черни Сонга", не в до-

${ }^{1}$ Имеются в виду слова, высеченные орхонским руническим письмом на стелах Бильге-кагана (строка 27: «С их ханом я сразился в черни Сонга») и Кюль-тегина (строка 35: «<..> с их каганом мы сразились в черни Сонга»). О походе тюркского войска в Хакасию зимой 711 г., говорится и в памятнике Тоньюкука (строки 23-28) [Малов 1951: 25, 32, 41, 58, 62, 63, 67; 1959: 12, 17, 20]. В полевой сезон 1971 г. названная в источниках местность была впервые установлена Л.Р. Кызласовым, увидевшим в хакасском имени долины Сорва ойм (Сорга), производном от гидронима Сор сув, морфологическое подобие «Сонга - долина р. Сон». Определение введено им в историческую литературу [Кызласов Л.Р. 1984: 40; 1993: 51]. Кыргызы - аристократический род средневековых хакасов, чернь (jыш/jï̌s) - хвойный горный лес (тайга).

Изначальное прочтение В.В. Радловым топонима $\checkmark$ y $>$ Suna/Суңа/Suna [Radloff 1894: 21, 59; Мелиоранский 1899: 73, 123, прим. 56, табл. I; Малов 1951; 1959] было повсеместно воспринято отечественной тюркологией [ДТС 1969: 514]. После определения Л.Р. Кызласовым места былой битвы [Кормушин 2008: 313] тюркологи изменили прочтение слова на Sona/Соңа, а то и Songa/Сонга [Кормушин 1997: 80, 81, 89 - Соңа; 2004: 141, 209, 211, 212; 2008: 119, 212, 213, 326; Тугушева 2008: 31, 45, $52,59,139,165,169$ - Songa]. Этому способствует руническая орфография, ибо знак обозначал обе гласные - и «u», и «о» (потому также изначально возникло и другое прочтение В. Томсена - Sona, создавшая на Западе свою традицию и оказавшееся прозорливым: Thomsen 1896: 109, 123; Orkun 1936: 46, 62; 1987: 46, 62; Tekin 1968: 369]. 
лине ли нынешней реки Сон, расположенной на следующей за [станцией] Ербинской долине, где станция Сон стоит. Как раз чернь - лиственничные леса в горах». Дней 10 спустя, когда после ливневых дождей часть грунта на западном склоне бугра оползла, близ юго-западного угла был зачищен внешний край, а в центре объекта произведена небольшая шурфовка, вдоль корешка записной книжки были дополнены соответствующие краткие записи: «Кирпичи шириной 26-30 см. В Ю3 углу видна неряшливая кладка тычок на тычок». «Кирпич размером 48×24 (25-26)×11 см. Тычок - ложок - тычок, так лежат» и «Заложил шурф $1 \times 1$ м в центре и на глубине около 2 м $(1,8$ м) - песок. Весь шурф - черная однородная засыпь».

Никаких сомнений о характере объекта не оставалось. Тогда же в ежегодник «Археологические открытия», предназначенный для скорого уведомления о результатах полевых работ в СССР, вслед за рассказом о раскопках древних святилищ с изваяниями и менгирами было дано и краткое сообщение: «В поселке у станции были обнаружены остатки редкого для Хакасии средневекового монументального здания (типа замка или храма размером $38 \times 32$ м и высотой 3 м), сложенного из камня и сырцового кирпича» [Кызласов Л.Р. 1972: 296].
Экспедиция кафедры археологии МГУ без задержки начала подготовку к раскопкам этого здания. Уже в августе 1971 г. для изучения методики раскопок сырцовых и глинобитных зданий Средней Азии студент И.Л. Кызласов был из г. Абакана послан на стажировку в г. Пенджикент, в экспедицию Ленинградского отделения ИА АН СССР и Государственного Эрмитажа, руководимую А.М. Беленицким и Б.И. Маршаком. Специфике раскопок его обучила В.И. Распопова, архитектурным обмерам - Л.Л. Гуревич.

В последующие два сезона руины монументального здания на станции Ербинская были раскопаны (рис. 1).

Изучение полученных материалов шло двумя путями. Сведения о полевых наблюдениях продолжали кратко публиковаться Л.Р. Кызласовым, а научная документация подробно предоставляться в полевых отчетах [Кызласов Л.Р. 1973a; 1974а]. Уже работы 1972 г., вскрывшие западную часть здания, позволили установить его датировку (указывался период VIII-IX вв.), не бытовое, а храмовое назначение, отметить основные особенности интерьера и вероятную принадлежность к манихейству [Кызласов Л.Р. 1973б: 13; Кызласов Л.Р.,

Наши тюркологи неверно указывают местонахождение [Тугушева 2008: 45, прим. 64; Кормушин 1997; 2004; 2008] и значение имени географического объекта - черни Сонга (И.В. Кормушин).

Оставляю лингвистам рассмотрение топонимических основ сор- и сон(возможно, русской адаптации хакасской или дохакасской соң-, известной среди гидронимов Хакасии с кетским наращением -зас «река» [Бутанаев 1995: 109], наделяемых аффиксом -ға/-үа для обозначения связанных с рекою мест. Равно как и вопрос о времени появления топонимов такого вида. В отношении рунической записи $\checkmark \curlyvee>\&$ напомню лишь слова В. Томпсена: «Я рассматриваю <.. > звук, изображённый

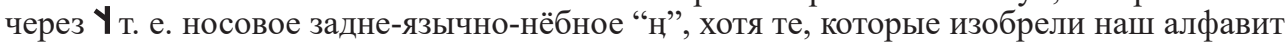
и те, которые им пользовались, быть может, скорее, рассматривали это начертание, как знак для сложного “ㄷ” < ...>» [цит. по: Мелиоранский 1899: 34]. 


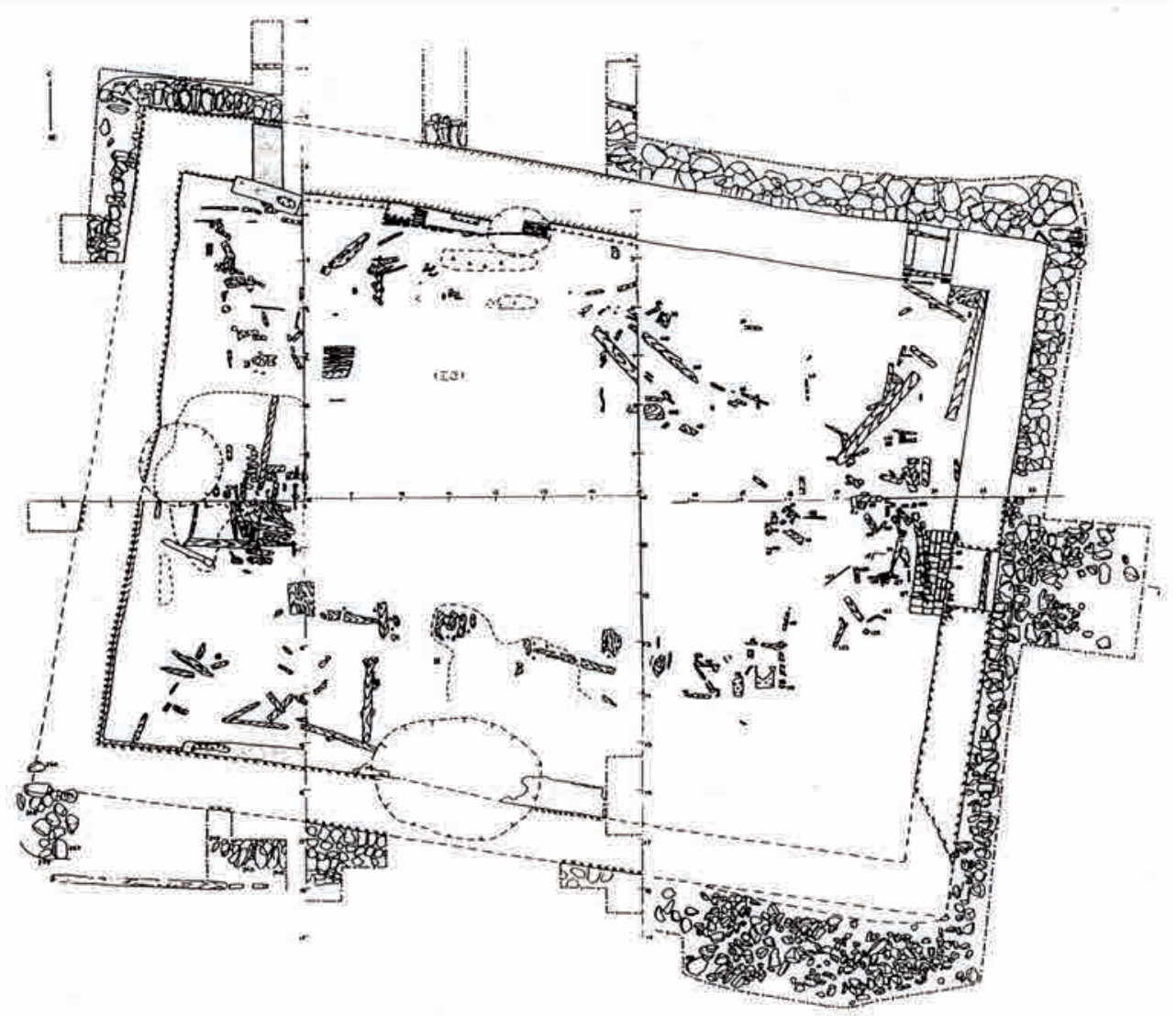

Рис. 1. Храм в котловине Сорга. План с камнями платформы и древесными остатками. Близ западной бровки - две деревянных базы колонн. Меж колами бровок 2 м

1-сур. Сорга қазаншұңқырындағы ғибадатхана. Платформа тастарымен және ағаш қалдықтарымен жоспар. Батыс жарқабаққа жақын - екі ағаш бағананың негізі.

Екі жарқабақтың арасы 2 м

Fig. 1. Temple in the basin of Sorga. Plan with platform stones and wood residues. Near the western edge - two wooden bases of columns. Between the edges $-2 \mathrm{~m}$

Кызласов И.Л. 1973: 222]. Раскопки 1973 г. подтвердили эти положения, выявили входные проемы, их устройство, представили общие характеристики строительного дела и использованных материалов [Кызласов Л.Р. 1974б].

Результаты раскопок демонстрировались и обсуждались на Всесоюзных конференциях [Кызласов Л.Р. 1975в], получили свое место в работах общего методического плана [Кызласов Л.Р. 1975г: 165, 166], в которых вновь высказывалась возможность связи храма в котловине Сорга с манихейской религией. Уже начиная с 1975 г., в выступлениях и публикациях Л.Р. Кызласова Ербинский храм рассматривался в сравнении с монументальными культовыми зданиями городского центра в низовьях Уйбата, которые обратили на себя внимание 
исследователя еще в 1959 г. [Кызласов Л.Р. 1992а: 97], и сразу же по окончанию работ в котловине Сорга вновь были обследованы им в 1973 г. [Кызласов Л.Р. 1974а: 211]². Затем эти объекты систематически раскапывались исследователем в течение 8-ми полевых сезонов - с 1974 г. по 1981 г. (см. АО за эти годы).

Именно это направление проведение крупномасштабных и длительных раскопочных работ во втором обнаруженном храмовомонастырском центре, обработка их результатов и постоянный сравнительный и обобщающий анализ всех материалов, полученных полевыми исследованиями 1972-1981 гг., - надолго заняло основное внимание ученого. Проведению полевых и камеральных работ способствовала кафедра археологии МГУ, год за годом выделявшая средства и направлявшая в экспедицию Л.Р. Кызласова на полевую практику немалое число студентов общей исторической и специальной археологической подготовки. Обычно в сезон раскопки занимали по два месяца: первую половину срока работали студенты, вторую - местные школьники. На раскопках огромных построек Уйбатского города число землекопов в месяц доходило до сотни. Каждый полевик знает какой сосредоточенности требует такая работа.
Подготовка к изданию результатов раскопок первого археологически изученного храма в долине Сорга была отложена. Их понимание оказалось сопряжено с исследованием вновь обнаруженных объектов такого рода. В общей сложности в низовьях Уйбата были обнаружены и раскопаны 6 храмов различного назначения и 5 святилищ природных стихий, а всего, вместе с ербинской, 12 монументальных культовых построек.

В полной мере осознавая значение сделанного открытия, Л.Р. Кызласов явно стремился сразу же ввести в профессиональный обиход совокупные, впервые полученные наукой данные о неведомом до того монументальном строительстве и сакральной архитектуре, в целом предъявить неколебимые археологические аргументы и, тем самым, изменить основы восприятия раннесредневековой истории Хакасско-Минусинской котловины и всей Южной Сибири, добиться нового понимания уровня ее социального и духовного развития в ту эпоху.

В библиографии Л.Р. Кызласова, связанной с постижением раскопанных храмов, выделяются два этапа. Один занимает 1980-е годы, второй формируется к 1997 г. С середины 1980-х годов выдвигается и вызревающая в этом поиске проблема становления в Сибири городской цивилизации.

${ }^{2}$ Тогда участникам маршрутных работ экспедиции, завершившим раскопки первого сырцового храма, показалось редкостным везением обнаружение новых монументальных зданий в первый же день поездки. Теперь понятно, что Л.Р. Кызласов не случайно остановил машину у больших бугров на Аскизском тракте - благодаря раскопкам на ст. Ербинской он понял особенности давно замеченных им бугров и знал куда ехать: «“Бугры” у Тутатчикова улуса (“Жданово”) были нами впервые осмотрены во время маршрута ХАЭ (Хакасской археологической экспедиции МГУ - И.К.) в 1959 г. и тогда уже по их конфигурации, отсутствию вертикально стоящих плит и микротопографии стало ясно, что мы имеем здесь дело не с могильными курганами, а с остатками сооружений иного рода, скорее всего - сырцовых или глинобитных зданий, дата которых без раскопок не могла быть определена» [Кызласов Л.Р. 1975д: 53]. 
Первый этап изучения полученHolх данных

Обнаружение в Хакасии городских центров VIII-XII вв. признавалось большим достижением [Кызласов Л.Р. 1980: 79]. Результаты раскопок Ербинского храма, как и храмов и (как тогда считалось) замка-дворца Уйбатского города, вошли в академическое издание «Археология СССР».

В нем руины в котловине Сорга были отнесены к выделяемому позднему копёнскому этапу культуры чаатас, относимому к VIII - первой половине IX в., а появление самого здания - к рубежу IX в. Текст давал вполне конкретные данные о параметрах, конструктивных частях и деталях, архитектурной текстуре, приемах возведения и строительной технике этого монументального сооружения. Тем было показано, что оно «воздвигнуто строителями, принадлежавшими к школе западного среднеазиатского и центральноазиатского, а не дальневосточного зодчества». В этой архитектурной традиции была выполнена и графическая реконструкция раскопанной постройки, представленная в сводной типолого-хронологической таблице.

Само здание воспринималось как особое, предназначенное для торжественных общественных сборов, и именовалось храм-дворец. Доказательства его культового назначения и связи с манихейством были получены позднее. Длительное использование здания сомнения не вызывало, хотя период бытования был определен осторожно («Вероятно, ербинский храм-дворец еще какое-то время существовал и во второй половине IX Х в.» [Кызласов Л.Р. 1981a: 50]). О том свидетельствовало обнаружение в здании части типичного сосуда, указанного уже в разделе о тюхтятской археологической культуре, бытовавшей в названное время. Предполагалось существование вокруг храма-дворца не оставившего внешних следов деревянного городка - современника возникавшего в ту пору большого города в низовьях р. Уйбат [Кызласов Л.Р. 1981a: 48, 50, рис. 28, Г; 1981б: 57, рис. 33, А]. Тот, уже в условиях последующей аскизской археологической культуры, дожил до монгольского нашествия [Кызласов И.Л. 1981: 203, рис. $74, \mathrm{~A}]$.

У археологической профессуры идеи обычно выражаются в устной форме задолго до их появления в печатном виде. Л.Р. Кызласов ввел изучение Ербинского храма-дворца и построек Уйбатского города в лекционные курсы [Кызласов Л.Р. 1982: 14; 1986a: 34, 35]. Затем краткое описание обоих культовых центров нашло место в монографии, обобщающей письменные и археологические свидетельства истории Южной Сибири в средние века. В ней речь идет об открытых раскопками крупных монументальных храмовых, дворцовых и административных зданиях. Большое поселение в низовьях Уйбата расценивалось как центральный столичный город - «своеобразный хакасский Орду-Балык» (т. е. Столичный город) $)^{3}$, чему способствовали раскопанные монументальные постройки, включая

зЭто наименование дано по аналогии с ранее установленным самим Л.Р. Кыз-

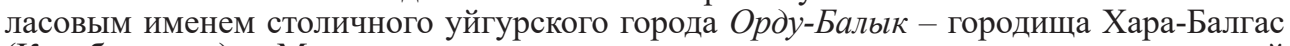
(Карабалгасун) в Монголии, отождествленным им при выделении археологической 
крупное четырехбашенное здание, подвергавшееся многим перестройкам и считавшееся за́мком, а также прослеженные остатки магистрального канала и правильной жилой планировки. Связанное с храмом поселение в котловине Сорга (на р. Бюре, хак. Пӱӱр суғ) воспринимается храмовым городком, для которого также было предложено соответствующее имя: «своеобразный Тигир-Балык», т. е. «Храмовый город» (ср. хакасское тигір иб «церковь», букв. божий (небесный) дом). Такому пониманию явно способствовал господствующий на местности единственный монументальный храм-дворец, поднимавшийся над землею, по крайней мере, на три метра. Названы его архитек- турные и строительные особенности, в том числе галереи с деревянными колоннами, окружавшие общий зал площадью около 800 кв. м [Кызласов Л.Р. 1984: 142-144] (рис. 1).

Эти исследовательские позиции, расценивавшие полученные археологические материалы как показатель раннесредневековой городской культуры, получили отражение и во впервые написанной академической «Истории Хакасии» [Кызласов Л.Р. 1993: 106, 107]. Вошли они и в пособия для учителей средней школы, в которых связывались с произошедшим в Древнехакасском государстве принятием манихейской религии [Кызласов Л.Р. 1989a: 46, 50; 1991a: 46, 50].

культуры Уйгурского каганата (745-840 гг.) с упомянутыми во второй половине XIII в. персидским автором Ала ад-дином Джувейни «следами города и дворца» Урду-Балыка (Мару-Балыка) [Кызласов Л.Р. 1959: 72; 1960а: 150; 1964а: 419; 1964б: 128; 1969: 56, 74, 77, 83; 1979: 150, 157; 1981 в: 52, 53; Кызласов, Левашёва 1965: 9, 10]. Имя города Орду-Балыка, не отмеченное в иных источниках, было реконструировано Л.Р. Кызласовым при помощи слов ordu - «ставка, резиденция» и balïq - «город», подобно наименованию городов в памятниках орхонского рунического письма, включая возведенный на Селенге в 757 г. «Богатый / Изобильный / Благоденствующий город» Бай-Балык

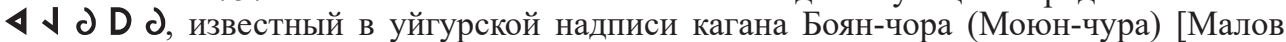
1951: 368; 1959: 30, 34, 92; ДТС 1969: 79, 80; Тугушева 2008: 117].

До отождествления с Орду-Балыком, произведенного археологом по переводам Джувейни, выполненным В.В. Радловым [Радлов 1893: 57, 59] и Н.Н. Туманович (рукопись, изученная во Фрунзе, вероятно, при пребывании там в 1953-1956 гг.) [Кызласов Л.Р. 1959: 72, прим. 20] столицу уйгурского каганата так и именовали по имени городища Хара-балгас, Карабалгасун и т. п. - см., напр.: [Киселев 1947: 371; 1957: 93, 95, 96; Тихонов 1966: 26-30, 200].

В ту пору соотнесение Хара-Балгасуна с уйгурской столицей Орду-Балыком, произведенное В.В. Бартольдом по тексту того же Джувейни в статье II тома «Enziklopaedie des Islam» (1927), не было известно Л.Р. Кызласову и было впервые издано по-русски много позднее [Бартольд 1965: 443]. К этому времени собственное имя столичного города, существовавшего на Орхоне в VIII-IX вв., уже было введено Л.Р. Кызласовым в советскую уйгуроведческую литературу. Отождествление произошло между 1957 (начало плановых раскопок Кызласовым уйгурских памятников) и 1959 гг. (первое упоминание). В ранней публикации [Кызласов Л.Р. 1954: 207] имя столицы Хара-Балгасун, вероятно, внесено при доработке текста в издательстве, т. к. в рукописи Л.Р. Кызласова, сданной в редакцию 10.10.1952 г. (личный архив), об уйгурах не говорится.

Имя города Орду-Балыка отсутствует в китайских источниках. Оно практически не встречается вне русского востоковедения и связанных с ним сочинений. (См., напр.: [Mackerras 1968; 1972]). В специальной статье об Орду-Балыке С.Г. Кляшторный [Кляшторный 2010] использует текст Джувейни в переводе Дж.Э. Бойла, изданный в 1958 г., не касаясь отечественной историографии данного вопроса. 
Начиная с 1985 г., осмысление открытых в Хакасии монументальных архитектурных комплексов VIIIXII вв. на базе раннесредневековых письменных источников направило мысль исследователя на выяснение крупной проблемы возникновения в Сибири городской цивилизации [Кызласов Л.Р. 1985; 1986б; 1990; 1991б; 1991в: 69-71; 1992a; 1992 и др.]. Эти изыскания, на которые в интересах нашей темы следует указать как на общий исторический фон проходивших в те годы поисков, углубляясь и расширяясь хронологически и историкокультурно, в итоге привели Л.Р. Кызласова к написанию последней в его жизни книги «Городская цивилизация Срединной и Северной Азии» [Кызласов Л.Р. 2006; Kyzlasov 2010].

Доклады, посвященные кирпичным архитектурным объектам, изученным в обоих городских центрах как в верховьях, так и в низовьях p. Уйбат, по понятным причинам делались, прежде всего, на казахстанских, среднеазиатских и сибирских археологических собраниях. Адресовались они и тюркологам. Среди сводных материалов о городской цивилизации тюркоязычных народов Южной Сибири в эпоху средневековья, представленных в сентябре 1985 г. Международному тюркологическому конгрессу в Стамбуле, нашли место и манихейские храмовые центры Хакасии [Кызласов Л.Р. 1987; 1988: 58, 59; 1989б: 401, 402].

Второй этап изучения полученHblx данных

Уже в начале работ на станции Ербинской Л.Р. Кызласов предполагал, что обнаруженное им монументальное здание могло иметь храмовое назначение и принадлежать к манихейской религии [Кызласов Л.Р., Кызласов И.Л. 1973: 222]. Леониду Романовичу, до этого впервые в науке определившему время бытования памятников енисейской рунической письменности и обосновавшему их культурную принадлежность [Кызласов Л.Р. 1960б; 1965в], было хорошо известно употребление в обнаруженной в 1900 г. Г.Й. Рамстедтом Суджинской надписи (Е 47, строка 7), весьма показательного термина $\mathbf{4} \gg \mathrm{m}(\mathrm{a}) \mathrm{r}$. Слово, до того не встречавшееся в рунике, было узнано там знаменитым дешифровщиком рунического письма Вильгельмом Томсеном, заключившим: «Здесь мы имеем манихейское и несторианское название mar “учитель, мастер”». Поскольку несторианство не применяло рунического письма, было справедливо отмечено, что «учитель [умершего] или mar был определенно манихейским ученым, и этот могильный камень рассказывает также о распространении и значении манихейства в конце восьмого века после Христа» [Ramstedt 1913: 4, 5, 7, 9]. Тем самым лингвисты ранней поры полагали, что эпитафия создана несколько позднее 763 г. - даты принятия манихейства в Уйгурском каганате. Однако памятник был написан енисейским письмом [Малов 1952: 84-90] и сооружён у кургана древнехакасского аристократа после разгрома этого центральноазиатского государства и относится к 840-860 гг. [Кызласов Л.Р. 1960б: 117, 120, № 47; 1965в: 49, прим. 42].

Задолго до обнаружения храма в котловине Сорга этот эпитафийный текст послужил основанием для Л.Р. Кызласова писать о существовании в Древнехакасском государстве манихейства, воспринятого к сере- 
дине IX в. частью знати в результате уйгурского влияния. В подтверждение этого привлекались сообщения Абу-Дулафа, побывавшего на Енисее в 942 г., и некоторые культовые изделия. Тогда представлялось, что манихейство не пустило глубоких корней ни в Хакасско-Минусинской, ни в Тувинской котловинах [Кызласов Л.Р. 1966: 24; 1969: 127, 128].

Сказанное объясняет, почему в подтверждение религиозной принадлежности ербинского здания Л.Р. Кызласов обратился к описаниям манихейских святилищ. Наше изложение истории открытия и изучения Ербинского храма приобретает здесь кольцевую композицию, поскольку в этих поисках исследователь, прежде всего, возобновил изучение публикаций о памятных ему храмах древнего Пенджикента.

Вновь такой выбор не был случаен. Письменные источники свидетельствовали о том, что манихейская религия проникла на восток от Средней Азии благодаря согдийским миссионерам. Как мы видели, личные среднеазиатские знания и опыт уже в 1971 г., при первом знакомстве с обнаруженным в котловине Сорга монументальным сооружением, позволили Л.Р. Кызласову заметить воздействие на него согдийской архитектурностроительной традиции. Раскопки последующих двух лет подтвердили эти наблюдения. Развитие раннесредневекового зодчества Согда прослежено главным образом на материалах храмовых комплексов Пенджикента - c V по первую половину VIII в. [Маршак 1999: 175-179].

В те годы существовало единственное исследование, специально посвященное идеологическому опре- делению раскопанных на согдийском городище храмов. А.М. Беленицкий при рассмотрении четырех возможных религиозных систем эпохи, к которым они могли принадлежать, в большой статье последовательно отверг восточное христианство, буддизм и зороастризм, заключив: «остается манихейство, как наиболее вероятный “претендент" на пянджикентские храмы. Эту гипотезу я и выдвигаю, и дальнейшее изложение посвящено посильному обоснованию ее» [Беленицкий 1954: 64]. В том же сборнике А.Ю. Якубовский оспорил манихейское определение храмов, справедливо считая, что «местные языческие культы и верования, имевшие свою длительную историю $<\ldots>$ в конкретной исторической обстановке <..> частично врастали в пришлые извне религии» и пенджикентские храмы, таким образом, являются выражением местных, согдийских форм культа огня и представлений об умирающих и воскресающих силах природы [Якубовский 1954: 21-23; ср. 1951: 253256]. И хотя обе мысли родоначальника Согдийско-Таджикской археологической экспедиции, ставшей затем Пенджикентской, подтвердились и детализировались в дальнейшем [Маршак 1999; Шкода 2009: 12-24 сл.], включая труды самого Александра Марковича [Беленицкий 1950: 7, 8; 1973a: 124-127; 1973б: 7-14, 42-46; Беленицкий и др. 1981: 107], Л.Р. Кызласов отыскал в глубоком, обильном источниками тексте А.М. Беленицкого необходимые ему письменные свидетельства.

Путеводной звездой в поиске сибирского археолога стали средневековые сообщения о развитой традиции астральных культов, отличавшей 
манихейство: «Без учета той части идеологического наследия, которое манихейцы получили от астрологовзвездопоклонников, именуемых арабами сабейцами (иноверцами), нельзя понять назначения раскопанных в Хакасии храмов и святилищ» [Кызласов Л.Р. 1998а: 15-16]. В этой области исследователем были выделены два мировоззренческих явления, связанных между собою причинноследственным образом.

Определяющими оказались идущие из древности взгляды, проявившиеся в храмовом зодчестве, - почитание 7-ми небесных светил привело к выработке и канонизации архитектурно-планиграфического символизма культовых сооружений, отличавшихся по форме для каждого из этих небесных тел и сакрально значимых космических явлений (рис. 2). Авестийские имена планет были названиями 7-ми дней недели в Согде до самой мусульманизации страны. На то прямо указывал календарь VIII в., найденный в руинах замка на горе Муг, равно как и сообщение в одновременном китайском источнике, относящееся к «согдийцам, персам и людям пяти Индий».

Продолжая поиски в арабских источниках, приведенный А.М. Беленицким [Беленицкий 1954: 65] перечень геометрического многообразия планировок манихейских храмов, содержащийся в сочинении алМасуди (Х в.), удалось подтвердить и дополнить свиде- тельствами аш-Шахристани (XII в.) и ад-Димешки (XIV в.). Эти данные позволили Л.Р. Кызласову во всех основных деталях понять встреченное им при раскопках ранее невиданное разнообразие устройства 7-ми храмовых зданий и 5-ти святилищ обоих культовых центров Хакасии и даже предположительно соотнести каждое из них с культом той или иной планеты или светила и выделяемого религиозной доктриной космогонического явления (рис. 3-5).

Близкие соответствия средневековых описаний и большой серии реальных археологически изученных культовых объектов окончательно убедили исследователя в их принадлежности к манихейской религии: 


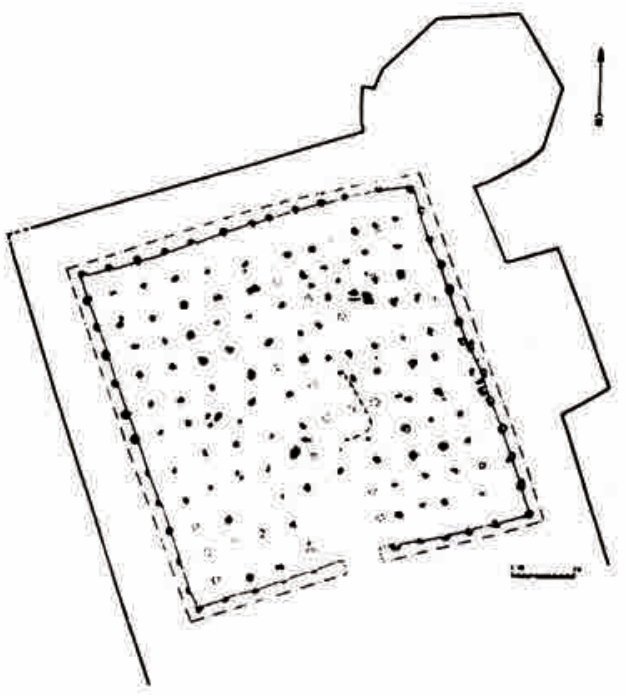

Рис. 3. Колонный зал храма Солнца Уйбатского города. С севера пристроен храм Луны, с востока - храм Воздуха. Линейный масштаб 4 м

3-сур. Уйбат қаласының Күн ғибадатханасының колонналы залы. Солтүстік жағында Ай ғибадатханасы, шығысында Ауа ғибадатханасы жалғап салынған. Сызықтық масштабы 4 м

Fig. 3. Column hall of the Temple of the Sun of the Uybat city. The Temple of the Moon is attached from the north, and the Temple of the Air - from the east. Linear scale $4 \mathrm{~m}$

совым к 1996 г., через 15 лет после завершения раскопок. С тех пор из его публикаций исчезли «храмы-дворцы», «замки» и «административные здания» - назначение всех строений получило обоснование в привлеченных к исследованию письменных источниках.

Археологическая характеристика ербинского храма и его сопоставление с храмом божества планеты Марс манихейской традиции были представлены археологом исследователям Средней Азии в докладе, сделанном перед лицом Пенджикентской экспедиции [Кызласов Л.Р. 1997: 28-29]. Исходя из датировки объекта, было высказано предположение, что арабский путешественник абу-Дулаф, в 942 г. побывавший на Енисее, мог посетить именно этот упомянутый им храм.

В начале марта 1997 г. в редакцию журнала «Российская археология» была сдана и лишь в 1999 г. вышла в свет большая ста-

«Опыт наших раскопок в "Уйбатском городе" свидетельствует, что искушенные манихейские зодчие канонизировали геометрические формы архитектурного построения храмов, которые они получили в наследство от своих предшественников астрологовзвездопоклонников. Каждый из изученных в Хакасии храмов посвящался лишь одному божеству из числа семи великих небесных светил или понятий» [Кызласов Л.Р. 1998а: 18].

Согласно рукописям домашнего архива, религиозная принадлежность храма в котловине Сорга и монументальных построек на Уйбате была окончательно установлена Л.Р. Кызла- тья, посвященная храму в котловине Сорга, ставшая публикацией полученных при раскопках основных археологических наблюдений, сравнительного описания согдийских строительноархитектурных особенностей, обоснования датировки, культурной и религиозной принадлежности здания. Издание содержало соответствующую графическую и фотографическую документацию, а также завершающий текст краткий очерк существования в Южной Сибири манихейства с указанием на занимаемое им официальное положение в Древнехакасском государстве [Кызласов Л.Р. 1999а]. Хотя религиозное назначение здания уже 
не вызывало у Л.Р. Кызласова сомнения, в тексте он иногда именовал описываемое строение «храм-дворец», к чему, вероятно, все еще побуждала автора огромная площадь зала.

Эта предварительная публикация дает ясные общие представления об объекте, процессе раскопок и полученных материалах ${ }^{4}$.

На новом этапе изучения раскопанные в Хакасии храмы стали серьезным доводом в пользу былого существования манихейства в Древнехакасском государстве, а расположение их скопления в большом городе в низовьях Уйбата, существовавшее много веков подряд, - свидетельством официального положения этой рели-

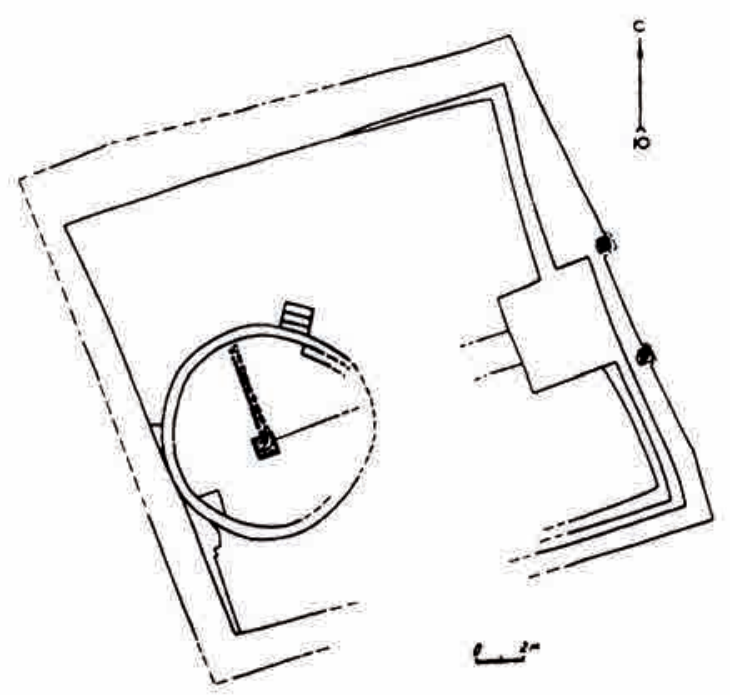
гии в стране. Именно так и предстают они в докладе, сделанном Л.Р. Кызласовым перед московскими востоковедами [Кызласов Л.Р. 1998б]. Другой доклад «о неведомых пока, но уже обретенных храмах религии “Истинного Света"» был им сделан в феврале 1999 г. в московском Доме ученых.

С тех пор основное внимание исследователя было обращено на уяснение условий возникновения и общих особенностей манихейского вероучения, его продвижения из Сасанидского Ирана на восток в Среднюю Азию, Восточный Туркестан и Китай, при-

нятия его в 763 г. Уйгурским каганатом, занятого положения в нем и проникновения в долины Среднего Енисея. Постижение самой манихейской доктрины должно было приблизить к пониманию одной из крупнейших загадок истории: вероучение, нигде не получившее официального признания и всюду гонимое как вредоносная секта и ересь, стало господствующей верой лишь в тюркоязычных державах раннего средневековья (добавим к двум названным Кимакский каганат и уйгурское княжество Кочо Восточного Туркестана). Почему именно они

${ }^{4}$ В личном архиве Л.Р. Кызласова сохранилась и небольшая рукопись «Манихейские храмы Южной Сибири. I. Храм в котловине Сорга» объемом 12 машинописных страниц с записью черной шариковой ручкой: «Этот окончательно отделанный текст не издавался. ЛК 16.XI. 98 г.». 


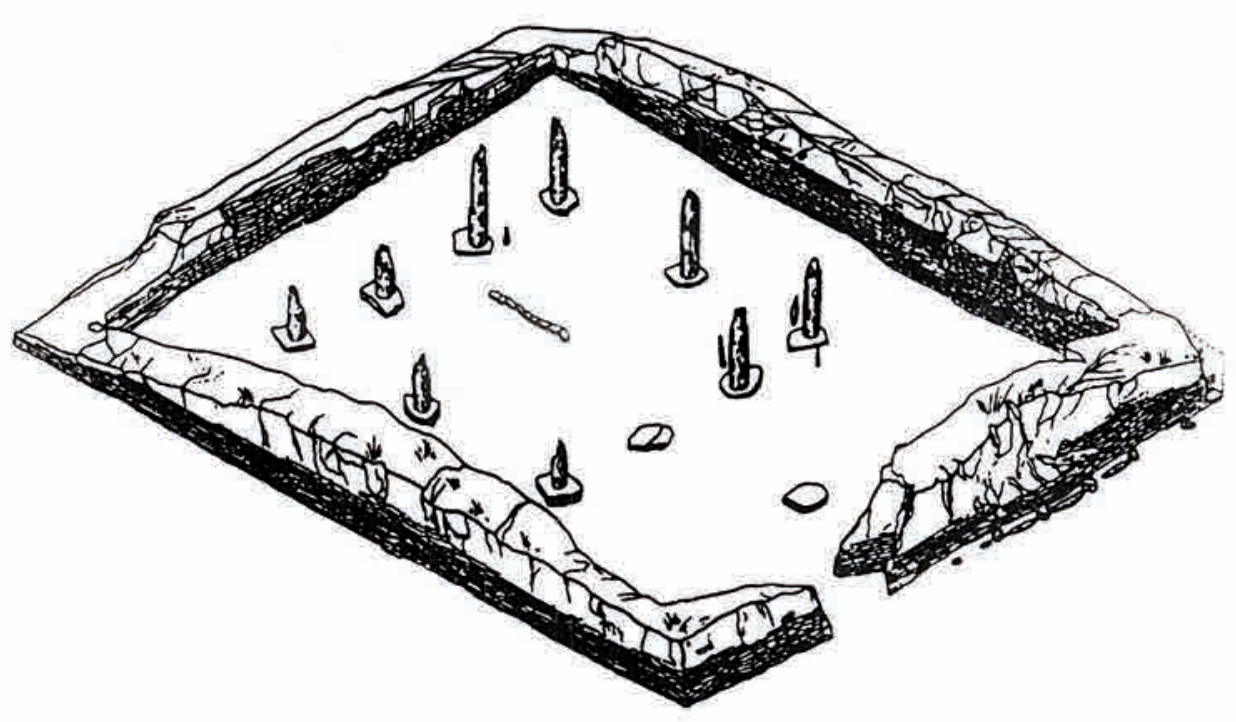

Рис. 5. Храм Марса Уйбатского города. Аксонометрия

5-сур. Уйбат қаласының Марс ғибадатханасы. Аксонометрия

Fig. 5. Temple of Mars of Uybat city. Axonometry

оказались особенно восприимчивыми к манихейскому мировоззрению, в чем оно оказалось близким именно их духовным исканиям? Сама постановка такого вопроса много значит для постижения названных исторических обстоятельств ${ }^{5}$.

\section{Bblвodbl}

Храм в котловине Сорга и культовые сооружения «Столичного города» на Уйбате занимают свое место в серии исследований Л.Р. Кызласова, характеризующих специфику впервые выявленного наукой сибирскотюркского манихейства, которое, по аналогии с бытующим разделением на адаптированное к христианству западное и «облаченное в буддийские одеяния» восточное манихейство [Литвинский, Смагина 1992: 526528], Л.Р. Кызласов нарёк северным [Кызласов Л.Р. 1998а; 1999в; 2000а], хотя продолжал именовать его и сибирским [Кызласов Л.Р. 1999б; 2000б; 2001].

Во всех этих изданиях в виду особой доказательной важности приведены описания и планы раскопанных храмов, включая и тот, что был изучен ранее прочих в котловине Сорга. После отдельной публикации 1999 г. получили подробное изложение и свидетельства согдийской принадлежности его строителей, с указанием известных архитектурных аналогий прослеженным деталям здания и соответствующей литературы

${ }_{5}^{5}$ Была попытка усмотреть один из мотивов в картине мира, состоящего по представлениям того времени из четырех великих империй, занимавших по одной из сторон света, и вероятным увязыванием такого устройства с фигурой Мани как последнего и четвертого в истории пророка Истины [Кызласов И.Л. 1999: 63-64, прим. 6]. 
[Кызласов Л.Р. 1998а: 24; 1999б: 27; 1999в: 17-29, рис. 9; 2000a: 71, 72; 2000б: 26, 27; 2001: 84].

Столь крупное открытие в нашем востоковедении существенно изменило былые представления о духовном развитии раннесредневековой Сибири и Центральной Азии. Л.Р. Кызласов увязывал с отразившими его особенностями само существование енисейской рунической письменности, символику орнаментированных изделий, видоизменения погребальных ритуалов и памятников, иные преобразования культуры, включая те следы манихейской идеологии, которые уцелели в поздних обрядовых действиях и лексике, отмеченных этнографией и языкознанием сибирских народов. На рубеже веков и в начале XXI в. исследователь как в кратких, так и в пространных вариантах активно публиковал, дорабатывал и переиздавал статьи об историко-культурной роли северного манихейства - будь то периодические издания сибирских научных учреждений или центральные археологические и этнографические журналы.

Эти богатые библиографией работы впервые вводили широкий круг читателей в основную проблематику малоизвестной ему манихейской духовности и в особенности ее поэтапного распространения среди иранои тюркоязычных народов раннего средневековья. Особенно насыщено этими данными издание Хакасской археологической экспедиции [Кызласов Л.Р. 1999в], вышедшее в жанре университетского семинарского пособия. Подробная статья Л.Р. Кызласова о северном манихействе и его роли в культурном развитии народов Сибири и Центральной Азии сопро- вождается в этой книжке пространной подборкой свидетельств, сравнительных и оценочных высказываний об учении и моральных принципах учения Мани, содержащихся в трех основных сочинениях Абу-р-Райхан ал-Бируни (973-1048 гг.) - одного из крупнейших ученых Востока. Тексты современника обнаруженных в Хакасии монументальных храмов сопровождены подробными комментариями, связывающими источник с археологическими и историческими реалиями Саяно-Алтая.

Именно эта тематика - воздействие манихейства на погребальные обычаи и облик археологических памятников, включая появление енисейских рунических эпитафий и надписей на бытовых предметах - была предложена к обсуждению на докладе Л.Р. Кызласова на сибиреведческой конференции в Санкт-Петербурге [Кызласов Л.Р. 2003а].

Серия последующих работ демонстрировала новизну изучения глубоких раннесредневековых культурных взаимосвязей тюркских и иранских народов, выявленных между известными и впервые полученными данными. Эти связи не только привели к появлению северного манихейства и строительству его первых монументальных храмов, возведенных в согдийских архитектурных традициях, но и создали основы для не существовавших прежде современных научных подходов к изучению многосложного культурного процесса, происходившего на просторах средневековой Евразии. Выделим те страницы, которые непосредственно касались прихода в Сибирь манихейской религии и появления ее храмов [Кызласов Л.Р. 2003б; 2004a: 12-17; 2004б: 128, 129; 2004в: 7-9; 2005: 457-460]. 
Готовя материалы для статьи в научно-популярном издании, вышедшем уже посмертно, Л.Р. Кызласов воспользовался возможностью не только описать архитектурные и строительные особенности храма в котловине Сорга, но и поведать о своеобразии мирного внедрения новой религии в местное общество, проявленное размещением этого культового здания среди неоскверненных древних святынь. Характер публикации позволил также обнародовать восемь цветных фотоснимков разных частей храма, сделанных во время его раскопок [Кызласов Л.Р. 2008а]. В той же книге был издан подробный иллюстрированный рассказ исследователя о манихейских храмах, раскопанных в Уйбатском городе [Кызласов Л.Р. 2008б].

За пару лет до этого материалы храма в котловине Сорга вошли в согласованный с Л.Р. Кызласовым средневековый раздел университетского учебника по археологии. В нем впервые указан важный элемент реконструкции зала - существование против входа светового люка, опиравшегося на четыре поставленных квадратом колонны. Манихейская принадлежность и связанный с нею галактический символизм этого культового здания, вероятно, посвященного богу планеты Марс, подтверждена описанием и планами монументальных сакральных построек Уйбатского города ранней поры (согласно построению определяемых как храм Первопричины Мира и храм Солнца) [Кызласов 2006: 567-569]. Указанные одновременные объекты включены в текст об археологической культуре чаатас (VI - первая половина IX в.), последующие, раскопанные в низовьях
Уйбата, - о тюхтятской (вторая половина IX - X в.) и аскизской культуpax (конец X-XVII в.) [Кызласов И.Л. 2006: 573-574, 577]. Учебник переиздавался в 2013 г. Готовится его третье издание.

Написанная уже без Леонида Романовича статья о Ербинском храме, говорящая о его связи с манихейством, сабейской архитектурной символикой и согдийскими строительными традициями, вошла в Большую Российскую Энциклопедию и, несмотря на краткость, впервые содержала указания на три этапа его существования, отраженные в изменениях интерьера [Кызласов И.Л. 2007]. На следующий год опыт археолога Л.Р. Кызласова в отыскании и раскапывании городов и храмовых комплексов Средней Азии и Южной Сибири, включая хакасские манихейские центры и описания культовой архитектуры верховий и низовий Уйбата, вошел в публикацию, обобщающую полевую методику исследователя [Кызласов И.Л. 2008: 2831, рис. 5-7]. В статье в Большой Российской Энциклопедии [Кызласов И.Л. 2016: 725, 726] охарактеризована не только сакральная, но и жилая часть Уйбатского города.

Современная малотиражность археологической литературы превращает ее в локальное явление. Любой материал, затрагивающий широкую тематику и обширные пространства, требует целевого извещения разных обособленных научных кругов. Поэтому результаты изучения раннесредневековых храмов и феномена северного, сибирско-тюркского манихейства, несмотря на уже значительную библиографию, были представлены во всероссийской аудитории, собиравшейся в Сибири [Кызласов И.Л. 
2017a], и среднеазиатским археологам, изучающим религии Шёлкового пути по проекту ЮНЕСКО. В последней публикации впервые издан сводный план здания с остатками древесных конструкций и вскрытыми участками сложенной из камней несущей платформы [Кызласов И.Л. 2017б: 122-124, рис. 2].

Остается отметить последние публикации, посвященные особенностям расположения монументальных манихейских храмов: их роли в образовании и длительном существовании Уйбатского города [Кызласов И.Л. 2019] и загадочному размещению храма в котловине Сорга среди густого скопления древних языческих идолов [Кызласов И.Л. 2020а]. Последнее обстоятельство позволило поставить и частично рассмотреть проблему отношения последующих культур к зримым памятникам предшествующих времен [Кызласов И.Л. 2020б].

\section{ЛИТЕРАТУРА}

1. Бартольд В.В. Каракорум // Сочинения. Т. 3. Работы по исторической географии. М.: Восточная литература, 1965. С. 443-444.

2. Беленицкий А.М. Раскопки здания № 1 на Шахристане Пянджикента (1947) // Труды Согдийско-Таджикской археологической экспедиции. Т. І. 1946-1947 / МИА, № 15. М.-Л.: Изд-во АН СССР, 1950. С. 100-105.

3. Беленицкий A.M. Вопросы идеологии и культов Согда по материалам пянджикентских храмов // Живопись древнего Пянджикента / Отв. ред. А.Ю. Якубовский, М.М. Дьяконов. М.: Изд-во АН СССР, 1954. С. 25-82.

4. Беленицкий A.M. Черты социальной и культурной жизни городского населения // Беленицкий А.М., Бентович И.Б., Большаков О.Г. Средневековый город Средней Азии. Л.: Наука, 1973a. С. 113-131.

5. Беленицкий А.М. Монументальное искусство Пенджикента. Живопись. Скульптура / Памятники древнего искусства. М.: Искусство, 1973б. $67+76$ с.

6. Белениикий А.М., Маршак Б.И., Распопова В.И. Согдийский город в начале средних веков // СА. 1981. № 2. С. 94-110.

7. Бутанаев В.Я. Топонимический словарь Хакасско-Минусинского края. Абакан: [б.и.], 1995. 267 с.

8. ДТС - Древнетюркский словарь. Ред.: В.М. Наделяев, Д.М. Насилов, Э.Р. Тенишев, А.М. Щербак. Л.: Наука, 1969. XXXVIII + 676 с.

9. Киселёв С.В. Монголия в древности // Известия АН СССР. Сер. истории и философии. 1947. T. IV. № 4. С. 354-372.

10. Киселёв С.В. Древние города Монголии // СА. 1957. № 2. С. 91-101.

11. Кляшторный С.Г. Ордубалык: рождение городской культуры в Уйгурском каганате // Древние культуры Евразии. СПб.: Инфо-ол, 2010. С. 276-279.

12. Кормушин И.В. Тюркские енисейские эпитафии. Тексты и исследования. М.: Наука, 1997. 303 с.

13. Кормушин И.В. Древние тюркские языки. Учебное пособие. Абакан: Изд-во Хакасского гос. ун-та, 2004. 336 с.

14. Кормушин И.В. Тюркские енисейские эпитафии. Грамматика, текстология. М.: Наука, 2008. 342 c.

15. Кызласов И.Л. Аскизская культура (средневековые хакасы X-XIV вв.) // Археология СССР. Степи Евразии в эпоху средневековья. / Отв. ред. С.А. Плетнева. М.: Наука, 1981. С. 200-207, 247-249. 
16. Кызласов И.Л. Мани и манихейство по свидетельствам Абу-р-Райхан ал-Бируни. Примечания // Открытие государственной религии древних хакасов / Ред. и сост. И.Л. Кызласов / Труды Хакасской археологической экспедиции. 7 (6): Университетская библиотека. Кн. 2. Манихейский семинар. Вып. 1. М.-Абакан: [б.и.], 1999. С. 42-77.

17. Кызласов И.Л. Глава 6. Средневековые государства Южной Сибири и Дальнего Востока // Археология. Учебник для вуз'ов. Ред. акад. В.Л. Янин. М.: Изд-во МГУ, 2006. С. 550-593.

18. Кызласов И.Л. Ербинский храм // Большая Российская Энциклопедия. М.: БРЭ, 2007, T. 2007. С. 684.

19. Кызласов И.Л. Стратегия археологических экспедиций: опыт Л.Р. Кызласова в отыскании и изучении городов Срединной Азии // Археологическая экспедиция: новейшие достижения в изучении историко-культурного наследия Евразии. М-лы Всеросс. науч. конф., посвящ. 35-летию со времени образования Камско-Вятской арх. экспедиции / Гл. ред. Р.Д. Голдина. Ижевск: Удмуртский ГУ, 2008. С. 21-38.

20. Кызласов И.Л. Уйбатское городище // Большая Российская Энциклопедия. М.: БРЭ, 2016. Т. 32. С. $725,726$.

21. Кызласов И.Л. Храмовый городской центр на р. Абакане (вторая половина VIII - начало ХІІІ в.). Раскопки Л.Р. и И.Л. Кызласовых (МГУ, ИА АН СССР/РАН) // V (XXI) Всероссийский археологический съезд. Сб. науч. тр. Барнаул: АлтГУ, 2017а. C. 602-603.

22. Кызласов И.Л. Манихейские храмы на Среднем Енисее (Исследования Л.Р. Кызласова) // Религии Казахстана и Центральной Азии на Великом Шелковом пути: м-лы междунар. науч.-практ. конф. (г. Алматы, 12-13 июня 2017 г.). Алматы: Центр сближения культур под эгидой ЮНЕСКО; Service Press, 2017б. С. 119-131.

23. Кызласов И.Л. Возникновение и формирование Уйбатского города (Хакасия). Градообразующая роль храмов VIII - начала XIII в. // КСИА. 2019. Вып. 256. С. 242-250.

24. Кызласов И.Л. Особенности археологического изучения южносибирского средневековья // КСИА. 2020а. Вып. 261. С. 313-327.

25. Кызласов И.Л. Восприятие последующими культурами памятников предыдущих. Историко-культурные особенности размещения храма в котловине Сорга́ // Археология Казахстана. 2020б. № 4. С. 24-46.

26. Кызласов И.Л. История открытия и изучения первого манихейского храма в Сибири. Часть 1 // Археология Казахстана. 2021. № 3 (13). С. 9-25.

27. Кызласов Л.Р. Древнейшая история Монголии по археологическим данным / Монгольская Народная республика. Исторический очерк // Большая Советская Энциклопедия. 2-е изд. М.: БСЭ, 1954. Т. 28. С. 206-207.

30. Кызласов Л.Р. Средневековые города Тувы // СА. 1959. № 3. С. 66-80.

31. Кызласов Л.Р. Тува в составе уйгурского каганата (VIII-IX вв.) // Уч. зап. Тувинского НИИЯЛИ. Кызыл: [б.и.], 1960а. Вып. VIII. С. 144-157.

32. Кызласов Л.Р. Новая датировка памятников енисейской письменности // СА. 1960б. № 3. С. 93-120.

33. Кызласов Л.Р. Южная Сибирь в эпоху владычества уйгуров // Материалы по древней истории Сибири. Улан-Удэ: [б.и.], 1964а. С. 413-426.

34. Кызласов Л.Р. Тува в составе уйгурского каганата (VIII-IX вв.) // История Тувы. М.: Наука, 1964б. Т. 1. С. 117-137.

35. Кызласов Л.Р. О датировке памятников енисейской письменности // СА. 1965в. № 3. C. 38-49.

36. Кыззласов Л.Р. История Тувы в средние века: автореф. дис. ... докт. ист. наук. М.: Изд-во Московского ун-та, 1966. 32 с. 
37. Кызласов Л.Р. История Тувы в средние века. М.: Изд-во Московского ун-та, 1969. $211 \mathrm{c}$.

38. Кьзласов Л.Р. Каменные «старушки» Хакасии // АО-1971. М.: Наука, 1972. C. 295-296.

39. Кызласов Л.Р. Отчет о работе Хакасской археологической экспедиции МГУ в 1972 году. М., 1973а // АИА РАН. Ф-1. Р-1, д. 4962, 61 л.; 4962а, 34 л., 36 илл.; 4962б, 26 л., 190 илл.

40. Кызласов Л.Р. Роль археологических источников для изучения истории малых народов Сибири // Проблемы этногенеза народов Сибири и Дальнего Востока: тез. докл. Всесоюзн. конф. Новосибирск: ИИФФ СО АН СССР, 1973б. С. 12-15.

41. Кызласов Л.Р. Отчет о работе Хакасской археологической экспедиции МГУ в 1973 году. М., 1974а // АИА РАН. Ф-1. Р-1. Д. 5096. 43 л. + вклейка; 5069а. 28 л., 154 илл.

42. Кызласов Л.Р. Раскопки средневекового здания в Хакасии // АО-1973. М.: Наука, 1974б. С. 209-211.

43. Кызласов Л.Р. Средневековые архитектурные сооружения Хакасии // Новейшие открытия советских археологов. Киев: Институт истории АН УСССР, 1975в. Ч. III. C. $117-118$.

44. Кызласов Л.Р. Роль археологических источников для изучения истории малых народов Сибири // История СССР. 1975г. №6. С. 164-168.

45. Кызласов Л.Р. Отчет о работе Хакаской археологической экспедиции МГУ в 1974 году. М., 1975д // АИА РАН. Ф-1. Р-1, д. 5457, 83 л.

46. Кызласов Л.Р. Древняя Тува. От палеолита до IX в. М.: Изд-во Московского ун-та, 1979. 207 с.

47. Кызласов Л.Р. Кафедре археологии исторического факультета МГУ 40 лет. Доклад на юбилейном заседании кафедры археологии 26 декабря 1979 г. // ВМУ. 1980. Серия 8. История. № 3. С. 77-80.

48. Кызласов Л.Р. Древнехакасская культура чаатас VI-IX вв. // Археология СССР. Степи Евразии в эпоху средневековья / Отв. ред. С.А. Плетнева. М.: Наука, 1981а. С. 46-52. Рис. 28, 29.

49. Кызласов Л.Р. Тюхтятская культура древних хакасов (IX-X вв.) // Археология CССР. Степи Евразии в эпоху средневековья / Отв. ред. С.А. Плетнева. М.: Наука, 1981б. С. 54-59, 101, 144-146, рис. 33, 34.

50. Кьзласов Л.Р. Культура древних уйгур (VIII-IX вв.) // Археология СССР. Степи Евразии в эпоху средневековья / Отв. ред. С.А. Плетнева. М.: Наука, 1981 в. С. 52-54.

51. Кызласов Л.Р. Средневековая археология Южной Сибири // Уральский государственный университет. Программа спецкурсов по археологии и этнографии. Свердловск: УрГУ, 1982. С. 13-16.

52. Кызласов Л.Р. История Южной Сибири в средние века / Библиотека историка. М.: Высшая школа, 1984. 167 с.

53. Кызласов Л.Р. Восточные источники о средневековых городах Южной Сибири // Достижения советских археологов в XI пятилетке: тез. докл. конф. Баку, 1985. C. $212-213$.

54. Кызласов Л.Р. Средневековая археология Сибири // Учебные программы. Археология. М.: Изд. Московского ун-та, 1986а. С. 34-37.

55. Кызласов Л.Р. Сообщения русских источников о древних и средневековых городах Сибири // Русский город / Ред. В.Л. Янин. М.: Из-во Моск. ун-та, 1986б. Вып. 8. C. $31-42$.

56. Кызласов Л.Р. Городская цивилизация тюркоязычных народов Южной Сибири в эпоху средневековья // Взаимодействие кочевых культур и древних цивилизаций: тез. докл. конф. Алма-Ата, 1987. С. 176-179. 
57. Кызласов Л.Р. Городская цивилизация тюркоязычных народов Южной Сибири в эпоху средневековья // Историко-культурные связи народов Южной Сибири. Абакан: [б.и.], 1988. С. 57-63.

58. Кызласов Л.Р. Древняя и средневековая история Южной Сибири (в кратком изложении). Пособие для учителя. Абакан: Хакасск. отделение Красноярского кн. издва, 1989a. 58 с.

59. Кызласов Л.Р. Городская цивилизация тюркоязычных народов Южной Сибири в эпоху средневековья // Взаимодействие кочевых культур и древних цивилизаций. Алма-Ата: Наука, 1989б. С. 400-406.

60. Кызласов Л.Р. Античная традиция о благословенном городе в центре Азии // Археология Средней Азии: тез. докл. конф. Ташкент: [б.и.], 1990. С. 60-62.

61. Кызласов Л.Р. Древняя и средневековая история Южной Сибири. В кратком изложении. Пособие для учителей истории. 2 изд. Абакан: Хакасск. отделение Красноярского кн. изд-ва, 1991 а. 58 с.

62. Кызласов Л.Р. О понятии «город» в древности и средневековье // ВМУ. 1991б. Серия 8. История, № 4. С. 43-48.

63. Кызласов Л.Р. Проблемы археологии Сибири эпохи металла // Материалы конф. «Археология и социальный прогресс». М.: ИА РАН, 1991в. Вып. 2. С. 64-71.

64. Кызласов Л.Р. Письменные известия о древних городах Сибири. М.: Изд-во Московского ун-та, 1992а. 135 с.

65. Кызласов Л.Р. О понятии «город» в древности и средневековье // Социальные пространственные структуры в стадиальной характеристике культурно-исторического процесса: тез. докл. конф. М., 1992б. С. 158-160.

66. Кызласов Л.Р. Древнехакасское государство (VI-XIII вв.). Политическая история // История Хакасии с древнейших времен до 1917 года / Отв. ред. Л.Р. Кызласов. М.: Наука; Восточная литература, 1993. С. 44-72.

67. Кызласов Л.Р. Средневековый манихейский храм в котловине Сорга (Республика Хакасия) // 50 лет раскопок древнего Пенджикента: тез. докл. науч. конф. (Пенджикент, 15-20 августа 1997 г.). Пенджикент: Пенджикентская гор. тип-фия, 1997. С. 27-28.

68. Кызласов Л.Р. Северное манихейство и его роль в культурном развитии народов Сибири и Центральной Азии // ВМУ. 1998а. Серия 8. История. № 3. С. 8-35.

69. Кызласов Л.Р. Неведомые храмы манихеев // Древние цивилизации Евразии. История и культура: тез. докл. конф. / Ред. А.В. Седов. М.: Институт востоковедения РАН, 1998б. С. 55-57.

70. Кызласов Л.Р. Манихейский храм в котловине Сорга (Республика Хакасия) // PA. 1999a. № 2. С. 181-206.

71. Кызласов Л.Р. Сибирское манихейство // Гуманитарные науки в Сибири. 1999б. № 3. C. 26-31.

72. Кьззласов Л.Р. Северное манихейство и его роль в культурном развитии народов Сибири и Центральной Азии // Открытие государственной религии древних хакасов. / Ред. и сост. И.Л. Кызласов / Труды Хакасской археологической экспедиции. 7 (6): Университетская библиотека. Кн. 2. Манихейский семинар. Вып. 1. М.-Абакан: [б.и.], 1999в. C. 10-41.

73. Кызласов Л.Р. Северное манихейство и его роль в культурном развитии народов Сибири и Центральной Азии // Древности Алтая. Известия Лаборатории археологии. Горно-Алтайск: Изд-во ГАГУ, 2000а. № 5. С. 66-81.

74. Кызласов Л.Р. Сибирское манихейство и его роль в культурном развитии народов Сибири и Центральной Азии // Хакасия. История и современность / Ученые записки Хакасского НИИЯЛИ, вып. ХХІ / Отв. ред. В.Н. Тугужекова. Новосибирск: Наука, 2000б. С. 12-37. 
75. Кызласов Л.Р. Сибирское манихейство // ЭО. 2001. № 5. С. 83-90.

76. Кызласов Л.Р. Манихейское мировоззрение и раннесредневековые археологические памятники // Степи Евразии в древности и средневековье. К 100-летию со дня рождения М.П. Грязнова. Кн. ІІ / Отв. ред. Ю.Ю. Пиотровский. СПб.: Изд-во ГЭ, 2003a. C. 249-250.

77. Кызласов Л.Р. Тюрко-иранское языковое взаимодействие (письменность и религия) // Дешт-и Кипчак и Золотая Орда в становлении культуры евразийских народов. М-лы конф. М.: ИСАА при МГУ, 2003б. С. 287-293.

78. Кызласов Л.Р. Историко-культурное взаимодействие иранских и тюркских народов в средние века (язык, письменность, религия) // ВМУ. 2004а. Серия 8. История, № 3. С. 5-20.

79. Кызласов Л.Р. Тюрко-иранские культурные взаимосвязи в эпоху средневековья (язык, письменность, религия) // Древности Алтая. Горно-Алтайск: Изд-во ГАГУ, 2004б. № 12. С. 123-133.

80. Кызласов Л.Р. Культурные взаимосвязи тюрков и иранцев в VI-ХІІІ вв. (язык, письменность, религия) // ЭО. 2004в. № 6. С. 3-13.

81. Кызласов Л.Р. Тюрко-иранское культурное и языковое взаимодействие в его историческом освещении // Центральная Азия. Источники, история, культура. М.: Восточная литература РАН, 2005. С. 450-463.

82. Кызласов Л.Р. Городская цивилизация Срединной и Северной Азии. Исторические и археологические исследования. М.: Восточная литература РАН, 2006. $360 \mathrm{c}$.

83. Кызласов Л.Р. Храм Марса в котловине Сорга // Сокровища культуры Хакасии / Наследие народов Российской Федерации. Вып. 10. М.: НИИЦентр, 2008а. С. 486491.

84. Кblзласов Л.Р. Священный город манихеев на реке Уйбат // Сокровища культуры Хакасии / Наследие народов Российской Федерации. Вып. 10. М.: НИИЦентр, 2008 б. C. $492-499$.

85. Кызласов Л.Р., Кызласов И.Л. Исследования на территории Хакасии // АО-1972. М.: Наука, 1973. С. 222-223.

86. Кызласов Л.Р., Левашёва В.П. Сергей Владимирович Киселев // Новое в советской археологии / МИА, № 130 / Отв. ред. Е.И. Крупнов. М.: Наука, 1965. C. $7-12$.

87. Литвинский Б.А., Смагина Е.Б. Манихейство // Восточный Туркестан в древности и раннем средневековье. Этнос, языки, религии. М.: Наука, Восточная литература, 1992. С. 508-532.

88. Малов С.Е. Памятники древнетюркской письменности. М.-Л.: Изд-во АН СССР, $1951.451 \mathrm{c}$.

89. Малов С.Е. Енисейская письменность тюрков. М.-Л.: Изд-во АН СССР, 1952. $116 \mathrm{c}$.

90. Малов С.E. Памятники древнетюркской письменности Монголии и Киргизии. М.-Л.: Изд-во АН СССР, 1959. $111 \mathrm{c.}$

91. Маршак Б.И. Согд в V-VIII вв. Идеология по памятникам искусства // Археология. Средняя Азия и Дальний Восток в эпоху средневековья. Средняя Азия в раннем средневековье. / Отв. ред. Г.А. Брыкина. М.: Наука, 1999. С. 175-191.

92. Мелиоранский П.М. Памятник в честь Кюль-Тегина // Записки Восточного отделения Русского археологического общества. СПб.: Тип-фия Академии наук, 1899. T. XII, вып. II-III. C. 1-144.

93. Радлов В.B. К вопросу об уйгурах // Записки имп. Академии наук. T. LXXII. Приложение № 2. СПб., 1893. 130 с.

94. Тихонов Д.И. Хозяйство и общественный строй уйгурского государства X-XIV вв. М.- Л.: Наука, 1966. 287 с. 
95. Тугушева Л.Ю. Тюркские рунические письменные памятники из Монголии. М.: Инсан, 2008. 192 с.

96. Шкода В.Г. Пенджикентские храмы и проблемы религии Согда (V-VIII века). СПб.: Изд-во Гос. Эрмитажа, 2009. 280 с.

97. Якубовский А.Ю. Древний Пянжикент // По следам древних культур. / Ред. Г.Б. Федоров. М.: Гос. изд-во культурно-просветительной лит-ры, 1951. С. 209-270.

98. Якубовский А.Ю. Вопросы изучения пянджикентской живописи // Живопись древнего Пянджикента. / Отв. ред. А.Ю. Якубовский, М.М. Дьяконов. М.: Изд-во АН CCCP, 1954. C. 8-24.

99. Kyzlasov L.R. The Urban Civilization of Northern and Innermost Asia. Historical and Archeological Research. Bucureşti - Brăila: Editura Academiei Române, Editura Istros a Muzeului Brăilei, 2010. 426 p.

100. Mackerras $C$. The Uighur Empire (744-840) according to the T'ang dynastic histories. Canberra: Australian National University Press, 1968. 226 p.

101. Mackerras C. The Uighur Empire (744-840) according to the T'ang dynastic histories. A Study in Uighur-Chinese Relations. Canberra: Australian National University Press, 1972. $226 \mathrm{p}$.

102. Orkun H.N. Eski türk yazıtları. Istanbul: Devlet Basımevi, 1936. I. 192 s.

103. Orkun H.N. Eski türk yazıtları / Türk Dil Kurumu Yayınları: 539. Ankara: Türk Tarih Kurumu Basımevi, 1987. $962 \mathrm{s.}$

104. Radloff $W$. Die alttürkischen Inschriften der Mongolei. Lfg. 1: Die denkmäler von Koscho-Zaidam. Saint Petersburg: [б.и.], 1894. 83 s.

105. Ramstedt G.J. Zwei uigurische runeninschriften in der Nord-Mongolei // Journal de la Société Finno-Ougrienne. T. XXX, fasc. 3. Helsinki, 1913. S. 1-70, вклейка.

106. Tekin T. A Grammar of Orkhoh Turkic/Indiana Univ. Publications. Uralic and Altaic Series. V. 69. Bloomington, 1968. 419 p.

107. Tomsen V. Inscriptions de l'Orkhon déchiffrées / Suomalais-ugrilaisen seuran toimituksia. V. - Mémoires de la Société Finno-Ougrienne. V. Helsingfors: Imprimerie de la Société de Littérature Finnoise, 1896. 224 p.

\section{REFERENCES}

1. Bartold, V.V. 1965. In: Sochineniya. T. 3. Raboty po istoricheskoy geografii (Works on historical geography). Moscow: "Vostochnaya literature" Publ., 443-444 (in Russian).

2. Belenitskiy, A. M. 1950. In: Trudy Sogdiysko-Tadzhikskoy arheologicheskoyekspeditsii (Proceedings of the Sogdian Tajik archaeological expedition). T. I. 1946-1947 / MIA, № 15. Moscow-Leningrad: Izd-vo AN SSSR, 100-105 (in Russian).

3. Belenitskiy, A. M. 1954. In: Yakubovskiy, A. Yu., Diyakonov, M. M. (eds.). Zhivopis drevnego Pyandzhikenta (Painting of the ancient Pyandzhikent). Moscow: Izd-vo AN SSSR, 25-82 (in Russian).

4. Belenitskiy, A. M. 1973a. In: Belenitskiy, A. M., Bentovich, I. B., Bolshakov, O. G. Srednevekovyi gorod Sredney Azii (Medieval city of Central Asia). Leningrad: "Nauka" Publ., 113-131 (in Russian).

5. Belenitskiy, A. M. 1973b. Monumentalnoe iskusstvo Pendzhikenta. Zhivopis. Skulptura / Pamyatniki drevnego iskusstva (Monumental art of Penjikent. Painting. Sculptures / Monuments of ancient art). Moscow: "Iskusstvo" Publ.

6. Belenitskiy, A. M., Marshak, B. I., Raspopova, V. I. 1981. In: Sovetskaya arheologiya (Soviet archaeology), 2, 94-110 (in Russian).

7. Butanaev, V. Ya. 1995. Toponimicheskiy slovar Hakassko-Minusinskogo kraya (Toponymic dictionary of the Khakass-Minusinsk region). Abakan: [b.i.] (in Russian).

8. Nadelyaev, V. M., Nasilov, D. M., Tenishev, E. R., Shcherbak, A. M. (eds.). 1969. Drevnetyurkskiy slovar (Ancient Turkic dictionary). Leningrad: "Nauka" Publ. (in Russian). 
9. Kiselyov, S. V. 1947. In: Izvestiya AN SSSR. Ser. istorii i filosofii (News of the USSR Academy of Sciences. Ser. of History and Philosophy), 4, 354-372 (in Russian).

10. Kiselyov, S. V. 1957. In: Sovetskaya arheologiya (Soviet archaeology), 2, 91-101 (in Russian).

11. Klyashtornyi, S. G. 2010. In: Drevnie kultury Evrazii (Ancient Cultures of Eurasia). Saint Petersburg: "Info-ol" Publ., 276-279 (in Russian).

12. Kormushin, I. V. 1997. Tyurkskie eniseyskie epitafii. Teksty i issledovaniya (Turkic Yenisei epitaphs. Texts and research). Moscow: "Nauka" (in Russian).

13. Kormushin, I. V. 2004. Drevnie tyurkskie yazyki. Uchebnoe posobie (Ancient Turkic languages. Study guide). Abakan: Hakas State University Publ. (in Russian).

14. Kormushin, I. V. 2008. Tyurkskie eniseyskie epitafii. Grammatika, tekstologiya (Turkic Yenisei epitaphs. Grammar, textology). Moscow: "Nauka" (in Russian).

15. Kyzlasov, I. L. 1981. In: Pletneva, S. A. (ed.). Arheologiya SSSR. Stepi Evrazii v epohu srednevekoviya (Archeology of the USSR. Steppes of Eurasia in the Middle Ages). Moscow: "Nauka" Publ., 200-207, 247-249 (in Russian).

16. Kyzlasov, I. L. 1999. In: Kyzlasov, I. L. (ed.). Otkrytie gosudarstvennoy religii drevnih hakasov. Trudy Hakasskoy arheologicheskoy ekspeditsii. 7 (6): Universitetskaya biblioteka. Kn. 2. Maniheyskiy seminar. Vyp. 1 (Discovery of the state religion of the ancient Khakass. Proceedings of the Khakass archaeological expedition. 7 (6): University Library. Book 2. The Manichaean Seminar. Issue 1). Moscow-Abakan: [b.i.], $42-77$ (in Russian).

17. Kyzlasov, I. L. 2006. In: Yanin, V. L. (ed.). Arheologiya. Uchebnik dlya vuz'ov (Archeology. Textbook for universities). Moscow: Moscow State University Publ., 550-593 (in Russian).

18. Kyzlasov, I. L. 2007. In: Bolshaya Rossiyskaya Enciklopediya (Great Russian encyclopedia). Moscow: Bolshaya Rossiyskaya Enciklopediya Publ., 684 (in Russian).

19. Kyzlasov, I. L. 2008. In: Goldina, R. D. (ed.). Arheologicheskaya ekspeditsiya: noveyshie dostizheniya $v$ izuchenii istoriko-kulturnogo naslediya Evrazii (Archaeological expedition: the latest advances in the study of historical and cultural heritage of Eurasia). Izhevsk: Udmurt State University, 21-38 (in Russian).

20. Kyzlasov, I. L. 2016. In: Bolshaya Rossiyskaya Enciklopediya (Great Russian encyclopedia). Moscow: Bolshaya Rossiyskaya Enciklopediya Publ., 725, 726 (in Russian).

21. Kyzlasov, I. L. 2017a. In: V (XXI) Vserossiyskiy arheologicheskiy s'ezd (V (XXI) AllRussian archaeological Congress). Barnaul: Altay State University, 602-603 (in Russian).

22. Kyzlasov, I. L. 2017b. In: Religii Kazahstana i Tsentralnoy Azii na Velikom Shelkovom puti (Religions of Kazakhstan and Central Asia on the Great Silk road). Almaty: Center for the rapprochement of cultures under the auspices of UNESCO; Service Press, 119-131 (in Russian).

23. Kyzlasov, I. L. 2019. In: Kratkie soobshcheniya Instituta arheologii (Brief reports of the Institute of Archaeology), 256, 242-250 (in Russian).

24. Kyzlasov, I. L. 2020a. In: Kratkie soobshcheniya Instituta arheologii (Brief reports of the Institute of Archaeology), 261, 313-327 (in Russian).

25. Kyzlasov, I. L. 2020b. In: Kazakhstan Archeology, 4, 24-46 (in Russian).

26. Kyzlasov, I. L. 2021. In: Kazakhstan Archeology, 3, 9-25 (in Russian).

27. Kyzlasov, L. R. 1954. In: Bolshaya Sovetskaya Enciklopediya. 2-e izd. Moscow: Bolshaya Sovetskaya Enciklopediya, vol. 28, 206-207 (in Russian).

30. Kyzlasov, L. R. 1959. In: Sovetskaya arheologiya (Soviet archaeology), 3, 66-80 (in Russian).

31. Kyzlasov, L. R. 1960a. In: Uchenye zapiski Tuvinskogo Nauchno-issledovatelskogo instituta yazyka, literatury, istorii (Scientific notes of the Tuva Scientific Research Institute of Language, Literature, History). Kyzyl: [b.i.], Vyp. VIII, 144-157 (in Russian).

32. Kyzlasov, L. P. 1960b. In: Sovetskaya arheologiya (Soviet archaeology), 3, 93-120 (in Russian). 
33. Kyzlasov, L. R. 1964a. In: Materialy po drevney istorii Sibiri (Materials on the ancient history of Siberia). Ulan-Ude: [b.i.], 413-426 (in Russian).

34. Kyzlasov, L. R. 1964b. In: Istoriya Tuvy (History of Tuva). Moscow: "Nauka" Publ., T. 1, 117-137 (in Russian).

35. Kyzlasov, L. R. 1965c. In: Sovetskaya arheologiya (Soviet archaeology), 3, 38-49 (in Russian).

36. Kyzlasov, L. R. 1966. Istoriya Tuvy v srednie veka: avtoref. dis. ... dokt. ist. Nauk (History of Tuva in the Middle Ages: abstract. dis. Doctor of Historical Sciences). Moscow: Moscow University (in Russian).

37. Kyzlasov, L.R. 1969. Istoriya Tuvy v srednie veka (The history of Tuva in the Middle Ages). Moscow: Moscow University (in Russian).

38. Kyzlasov, L. R. 1972. In: Arheologicheskie otkrytiya-1971 (Archaeological discoveries-1971). Moscow: "Nauka" Publ., 295-296 (in Russian).

39. Kyzlasov, L. R. 1973a. In: Archive of the Institute of Archeology of the Russian Academy of Sciences. F-1. R-1, d. 4962, 61 1.; 4962a, 34 1., 36 ill.; 4962b, 26 1., 190 ill. (in Russian).

40. Kyzlasov, L. R. 1973b. In: Problemy etnogeneza narodov Sibiri i Dalnego Vostoka (Problems of the ethnogenesis of the peoples of Siberia and the Far East). Novosibirsk: Institute of history, philology and philosophy of the Siberian branch of the USSR Academy of sciences, 12-15 (in Russian).

41. Kyzlasov, L. R. 1974a. In: Archive of the Institute of Archeology of the Russian Academy of Sciences. F-1. R-1. D. 5096. 43 1.; 5069a. 28 1., 154 ill. (in Russian).

42. Kyzlasov, L. R. 1974b. In: Arheologicheskie otkrytiya-1971 (Archaeological discoveries-1971). Moscow: "Nauka" Publ., 209-211 (in Russian).

43. Kyzlasov, L. R. 1975c. In: Noveyshie otkrytiya sovetskih arheologov (The latest discoveries of Soviet archaeologists). Kiev: Institute of History of the Academy of Sciences of the USSR, ch. III, 117-118 (in Russian).

44. Kyzlasov, L. R. 1975d. In: Istoriya SSSR (History of USSR), 6, 164-168 (in Russian).

45. Kyzlasov, L. R. 1975e. In: Archive of the Institute of Archeology of the Russian Academy of Sciences. F-1. R-1, d. 5457, 83 1. (in Russian).

46. Kyzlasov, L. R. 1979. Drevnyaya Tuva. Ot paleolita do IX v. (Ancient Tuva. From the Paleolithic to the $9^{\text {th }}$ century). Moscow: Moscow University (in Russian).

47. Kyzlasov, L. R. 1980. In: Bulletin of the Moscow University. Seriya 8. Istoriya, 3, 77-80 (in Russian).

48. Kyzlasov, L. R. 1981a. In: Pletneva, S. A. (ed.). Arheologiya SSSR. Stepi Evrazii $v$ epohu srednevekoviya (Archeology of the USSR. Steppes of Eurasia in the Middle Ages). Moscow: "Nauka" Publ., 46-52, fig. 28, 29 (in Russian).

49. Kyzlasov, L. R. 1981b. In: Pletneva, S. A. (ed.). Arheologiya SSSR. Stepi Evrazii $v$ epohu srednevekoviya (Archeology of the USSR. Steppes of Eurasia in the Middle Ages). Moscow: "Nauka" Publ., 54-59, 101, 144-146, fig. 33, 34 (in Russian).

50. Kyzlasov, L. R. 1981c. In: Pletneva, S. A. (ed.). Arheologiya SSSR. Stepi Evrazii $v$ epohu srednevekoviya (Archeology of the USSR. Steppes of Eurasia in the Middle Ages). Moscow: "Nauka" Publ., 52-54 (in Russian).

51. Kyzlasov, L. R. 1982. In: Uralskiy gosudarstvennyi universitet. Programma speckursov po arheologii i etnografii (Ural State University. The program of special courses in archeology and ethnography). Sverdlovsk: Ural State University, 13-16 (in Russian).

52. Kyzlasov, L. R. 1984. In: Biblioteka istorika (Library of the historian). Moscow: "Vysshaya shkola" Publ. (in Russian).

53. Kyzlasov, L. R. 1985. Dostizheniya sovetskih arheologovvXI pyatiletke (Achievements of Soviet archaeologists in the XI five-year plan). Baku, 212-213 (in Russian). 
54. Kyzlasov, L. R. 1986a. In: Uchebnye programmy. Arheologiya (Educational programs. Archeology). Moscow: Moscow University, 34-37 (in Russian).

55. Kyzlasov, L. R. 1986b. In: Yanin, V. L. (ed.). Russkiy gorod (Russian City). Moscow: Moscow University, vol. 8, 31-42 (in Russian).

56. Kyzlasov, L. R. 1987. In: Vzaimodeystvie kochevyh kultur i drevnih tsivilizatsiy (Interaction of nomadic cultures and ancient civilizations). Alma-Ata, 176-179 (in Russian).

57. Kyzlasov, L. R. 1988. In: Istoriko-kulturnye svyazi narodov Yuzhnoy Sibiri (Historical and cultural ties of the peoples of Southern Siberia). Abakan: [b.i.], 57-63 (in Russian).

58. Kyzlasov, L. R. 1989a. Drevnyaya i srednevekovaya istoriya Yuzhnoy Sibiri (v kratkom izlozhenii). Posobie dlya uchitelya (Ancient and medieval history of Southern Siberia). Abakan: Hakassk. otdelenie Krasnoyarskogo kn. izd-va (in Russian).

59. Kyzlasov, L. R. 1989b. In: Vzaimodeystvie kochevyh kultur i drevnih tsivilizatsiy (Interaction of nomadic cultures and ancient civilizations). Alma-Ata: "Nauka" Publ., 400-406 (in Russian).

60. Kyzlasov, L. R. 1990. In: Arheologiya Sredney Azii (Archeology of Central Asia). Tashkent: [b.i.], 60-62 (in Russian).

61. Kyzlasov, L. R. 1991a. Drevnyaya i srednevekovaya istoriya Yuzhnoy Sibiri. $V$ kratkom izlozhenii. Posobie dlya uchiteley istorii. $2 \mathrm{izd}$. (Ancient and medieval history of Southern Siberia. In brief. A manual for history teachers. 2nd ed.). Abakan: Hakassk. otdelenie Krasnoyarskogo kn. izd-va (in Russian).

62. Kyzlasov, L. R. 1991b. In: Bulletin of the Moscow University. Seriya 8. Istoriya, 4, 43-48 (in Russian).

63. Kyzlasov, L. R. 1991c. In: Materialy konf. "Arheologiya i socialnyi progress» (Materials of the conf. "Archeology and social progress"). Moscow: Institute of Archaeology of RAS, vol. 2, 64-71 (in Russian).

64. Kyzlasov, L. R. 1992a. Pismennye izvestiya o drevnih gorodah Sibiri (Written news about the ancient cities of Siberia). Moscow: Moscow University Publ. (in Russian).

65. Kyzlasov, L. R. 1992b. In: Socialnye prostranstvennye struktury v stadialnoy harakteristike kulturno-istoricheskogo protsessa (Social spatial structures in the stadial characteristics of the cultural and historical process) Moscow, 158-160 (in Russian).

66. Kyzlasov, L. R. 1993. In: Kyzlasov, L.R. (ed.). Istoriya Hakasii s drevneyshih vremen do 1917 goda (The history of Khakassia from ancient times to 1917). Moscow: "Nauka" Publ.; "Vostochnaya literature" Publ., 44-72 (in Russian).

67. Kyzlasov, L. R. 1997. In: 50 let raskopok drevnego Pendzhikenta (50 years of excavation of ancient Penjikent). Pendzhikent: Pendzhikentskaya gor. tip-fiya, 27-28 (in Russian).

68. Kyzlasov, L. R. 1998a. In: Bulletin of the Moscow University. Seriya 8. Istoriya, 3, 8-35 (in Russian).

69. Kyzlasov, L. R. 1998b. In: Sedov, A. V. (ed.). Drevnie tsivilizatsii Evrazii. Istoriya $i$ kultura (Ancient civilizations of Eurasia. History and culture). Moscow: Institute of Oriental studies RAS, 55-57 (in Russian).

70. Kyzlasov, L. R. 1999a. In: Rossiyskaya arheologiya (Russian archeology), 2, 181-206 (in Russian).

71. Kyzlasov, L. R. 1999b. In: Gumanitarnye nauki v Sibiri, 3, 26-31 (in Russian).

72. Kyzlasov, L. R. 1999c. In: Kyzlasov, I. L. (ed.). Otkrytie gosudarstvennoy religii drevnih hakasov. Trudy Hakasskoj arheologicheskoj ekspedicii. 7 (6): Universitetskaya biblioteka. Kn. 2. Maniheyskiy seminar. Vyp. 1 (Discovery of the state religion of the ancient Khakas. Proceedings of the Khakass archaeological expedition. 7 (6): University Library. Book 2. The Manichaean Seminar. Issue 1). Moscow-Abakan: [b.i.], 10-41 (in Russian).

73. Kyzlasov, L. R. 2000a. In: Drevnosti Altaya. Izvestiya Laboratorii arheologii, 5, 66-81 (in Russian). 
74. Kyzlasov, L. R. 2000b. In: Tuguzhekova, V. N. (ed.). Hakasiya. Istoriya i sovremennost. Uchenye zapiski Hakasskogo NIIYALI, vyp. XXI (Khakassia. History and modernity. Scientific Notes of the Khakass Research Institute). Novosibirsk: "Nauka" Publ., 12-37 (in Russian).

75. Kyzlasov, L. R. 2001. In: Etnograficheskoe obozrenie, 5, 83-90 (in Russian).

76. Kyzlasov, L. R. 2003a. In: Piotrovskiy, Yu. Yu. (ed.). Stepi Evrazii v drevnosti $i$ srednevekovie (Steppes of Eurasia in antiquity and the Middle Ages). Saint Petersburg: State Hermitage Publ., 249-250 (in Russian).

77. Kyzlasov, L. R. 2003b. In: Desht-i Kipchak i Zolotaya Orda v stanovlenii kultury evraziyskih narodov (Desht-i Kipchak and the Golden Horde in the formation of the culture of the Eurasian peoples). Moscow: Moscow State University, 287-293 (in Russian).

78. Kyzlasov, L. R. 2004a. In: Bulletin of the Moscow University. Seriya 8. Istoriya, 3, 5-20 (in Russian).

79. Kyzlasov, L. R. 2004b. In: Drevnosti Altaya, 12, 123-133 (in Russian).

80. Kyzlasov, L. R. 2004c. In: Etnograficheskoe obozrenie, 6, 3-13 (in Russian).

81. Kyzlasov, L. R. 2005. In: Centralnaya Aziya. Istochniki, istoriya, kultura (Central Asia. Sources, history, culture). Moscow: "Vostochnaya literature", 450-463 (in Russian).

82. Kyzlasov, L. R. 2006. Gorodskaya tsivilizatsiya Sredinnoy $i$ Severnoy Azii. Istoricheskie $i$ arheologicheskie issledovaniya (Urban civilization of Central and Northern Asia. Historical and archaeological research). Moscow: "Vostochnaya literature" Publ. (in Russian).

83. Kyzlasov, L. R. 2008a. In: Sokrovishcha kultury Hakasii. Nasledie narodov Rossiyskoy Federatsii. Vyp. 10 (Treasures of culture of Khakassia. Heritage of the peoples of the Russian Federation). Moscow.: "NIICentr" Publ., 486-491 (in Russian).

84. Kyzlasov, L. R. 2008b. In: Sokrovishcha kultury Hakasii. Nasledie narodov Rossiyskoy Federatsii. Vyp. 10 (Treasures of culture of Khakassia. Heritage of the peoples of the Russian Federation). Moscow.: "NIICentr" Publ., $492-499$ (in Russian).

85. Kyzlasov, L. R., Kyzlasov, I. L. 1973. In: Arheologicheskie otkrytiya-1972 (Archaeological discoveries-1972). Moscow: "Nauka" Publ., 222-223 (in Russian).

86. Kyzlasov, L. R., Levashyova, V. P. 1965. In: Krupnov, E. I. (ed.). Novoe v sovetskoy arheologii. MIA, 130 (New in Soviet archaeology). Moscow: "Nauka" Publ., 7-12 (in Russian).

87. Litvinskiy, B. A., Smagina, E. B. 1992. In: Vostochnyi Turkestan v drevnosti i rannem srednevekovie. Etnos, yazyki, religii (East Turkestan in antiquity and the early middle ages. Ethnos, languages, religions). Moscow: "Nauka" Publ.; "Vostochnaya literature", 508-532 (in Russian).

88. Malov, S. E. 1951. Pamyatniki drevnetyurkskoy pismennosti (Monuments of ancient Turkic writing). Moscow-Leningrad: Academy of sciences of USSR (in Russian).

89. Malov, S. E. 1952. Eniseyskaya pismennost tyurkov (Yenisei writing of the Turks). Moscow-Leningrad: Academy of sciences of USSR (in Russian).

90. Malov, S. E. 1959. Pamyatniki drevnetyurkskoy pismennosti Mongolii i Kirgizii (Monuments of ancient Turkic writing in Mongolia and Kyrgyzstan). Moscow-Leningrad: Academy of sciences of USSR (in Russian).

91. Marshak, B. I. 1999. In: Brykina, G. A. (ed.). Arheologiya. Srednyaya Aziya i Dalniy Vostok v epohu srednevekoviya. Srednyaya Aziya v rannem srednevekovie (Archeology. Central Asia and the Far East in the Middle Ages. Central Asia in the Early Middle Ages). Moscow: "Nauka" Publ., 175-191 (in Russian).

92. Melioranskiy, P. M. 1899. In: Zapiski Vostochnogo otdeleniya Russkogo arheologicheskogo obshchestva (Notes of the Eastern Branch of the Russian Archaeological Society), T. XII, vol. II-III, 1-144 (in Russian).

93. Radlov, V. V. 1893. In: Zapiski imp. Akademii nauk (Notes of the Imp. Academy of Sciences), T. LXXII. Prilozhenie № 2 (in Russian). 
94. Tikhonov, D. I. 1966. Khozyaistvo i obshchestvennyi stroy uygurskogo gosudarstva $X-X I V v v$. (Economy and social system of the Uighur state of the $10^{\text {th }}-14^{\text {th }}$ centuries). Moscow-Leningrad: "Nauka" Publ. (in Russian).

95. Tugusheva, L. Yu. 2008. Tyurkskie runicheskie pismennye pamyatniki iz Mongolii (Turkic runic written monuments from Mongolia). Moscow: "Insan" (in Russian).

96. Shkoda, V. G. 2009. Pendzhikentskie hramy i problemy religii Sogda (V-VIII veka) (Penjikent temples and problems of religion of Sogd ( $5^{\text {th }}-8^{\text {th }}$ centuries). Saint Petersburg: State Hermitage Publ. (in Russian).

97. Yakubovskiy, A. Yu. 1951. In: Fedorov, G. B. (ed.). Po sledam drevnih kultur (In the footsteps of ancient cultures). Moscow: Gos. izd-vo kulturno-prosvet. Lit., 209-270 (in Russian).

98. Yakubovskiy, A. Yu. 1954. In: Yakubovskiy, A. Yu., Diyakonov, M. M. (eds.). Zhivopis drevnego Pyandzhikenta (Painting of ancient Panjikent). Moscow: Academy of sciences of USSR, 8-24 (in Russian).

99. Kyzlasov, L. R. 2010. The Urban Civilization of Northern and Innermost Asia. Historical and Archeological Research. Bucureşti - Brăila: Editura Academiei Române, Editura Istros a Muzeului Brăilei.

100. Mackerras, C. 1968. The Uighur Empire (744-840) according to the T'ang dynastic histories. Canberra: Australian National University Press.

101. Mackerras, C. 1972. The Uighur Empire (744-840) according to the T'ang dynastic histories. A Study in Uighur-Chinese Relations. Canberra: Australian National University Press.

102. Orkun, H. N. 1936. Eski türk yazıtları. Istanbul: Devlet Basımevi, I.

103. Orkun, H. N. 1987. Eski türk yazıtları / Türk Dil Kurumu Yayınları: 539. Ankara: Türk Tarih Kurumu Basımevi.

104. Radloff, W. 1894. Die alttürkischen Inschriften der Mongolei. Lfg. 1: Die denkmäler von Koscho-Zaidam. Saint Petersburg: [б.и.].

105. Ramstedt, G. J. 1913. In: Journal de la Société Finno-Ougrienne. T. XXX, fasc. 3. Helsinki, S. 1-70, вклейка.

106. Tekin, T. 1968. A Grammar of Orkhoh Turkic / Indiana Univ. Publications. Uralic and Altaic Series. V. 69. Bloomington.

107. Tomsen, V. 1896. Inscriptions de l'Orkhon déchiffrées / Suomalais-ugrilaisen seuran toimituksia. V. - Mémoires de la Société Finno-Ougrienne. V. Helsingfors: Imprimerie de la Société de Littérature Finnoise.

Мүдделер қақтығысы туралы ақпаратты ашу. Автор мүдделер қақтығысының жоқтығын мәлімдейді.

/ Раскрытие информации о конфликте интересов. Автор заявляет об отсутствии конфликта интересов.

/ Disclosure of conflict of interest information. The author claims no conflict of interest.

Мақала туралы ақпарат / Информация о статье / Information about the article.

Редакцияға түсті / Поступила в редакцию / Entered the editorial office: 21.10.2021.

Рецензенттер мақұлдаған / Одобрено рецензентами / Approved by reviewers: 30.10.2021.

Жариялауға қабылданды / Принята к публикации / Accepted for publication: 30.10.2021. 